\title{
How to resolve Pleistocene stratigraphic problems by different methods? A case study from eastern Poland
}

\author{
Sławomir TERPIŁOWSKI ${ }^{1, *}$, Tomasz ZIELIŃSKI ${ }^{2}$, Jarosław KUSIAK ${ }^{1, * *}$, Irena A. PIDEK ${ }^{1}$, Piotr CZUBLA ${ }^{3}$, \\ Anna HRYNOWIECKA ${ }^{4}$, Anna GODLEWSKA ${ }^{1}$, Paweł ZIELIŃSKI ${ }^{1}$ and Marzena MAŁEK ${ }^{5}$ \\ 1 Maria Curie-Skłodowska University, Department of Geoecology and Palaeogeography, Kraśnicka 2c,d, 20-718 Lublin, \\ Poland \\ 2 Adam Mickiewicz University, Institute of Geology, Maków Polnych 16, 61-606 Poznań, Poland \\ 3 Łódź University, Laboratory of Geology, Narutowicza 88, 90-139 Łódź, Poland \\ 4 Polish Geological Institute - National Research Institute, Marine Geology Branch, Kościerska 5, 80-328 Gdańsk, Poland \\ 5 Geological Enterprise POLGEOL S.A., Lublin Office, Budowlana 26, 20-469 Lublin, Poland
}

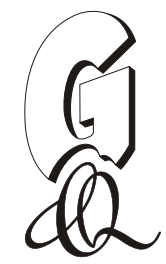

\begin{abstract}
Terpiłowski, S., Zieliński, T., Kusiak, J., Pidek, I., A., Czubla, P., Hrynowiecka, A., Godlewska, A., Zieliński, P., Małek, M., 2014. How to resolve Pleistocene stratigraphic problems by different methods? A case study from eastern Poland. Geological Quarterly, 58 (2): 235-250, doi: 10.7306/gq.1158

Different methods have been used to determine the stratigraphic position of Pleistocene alluvial deposits, particularly fluvial interglacial deposits. Near-surface deposits of a meandering river, developed in point-bar and oxbow lake facies, in the Samica River valley (near Łuków, eastern Poland) have been investigated. The fossil valley is incised into the till plain and the outwash. The fluvial succession is locally overlain by solifluction deposits. All the deposits underwent sedimentological analysis. The petrographic composition of basal till occurring in the vicinity of a fossil valley was determined with the method of indicator erratics. Fluvial deposits were examined by pollen analysis and plant macrofossil analysis of oxbow lake facies. Absolute dating methods were applied to the deposits (thermoluminescence methods: TL and additionally IRSL) Lithological differences between fluvial and the surrounding glaciofluvial deposits were identified and their lithostratigraphic position assigned. Petrographic analysis of till and palaeobotanical analyses of oxbow lake facies gave compatible results. Fluvial deposits were formed after the Sanian 2/Elsterian Glaciation, during the Mazovian/Holsteinian Interglacial. Luminescence dating of the fluvial deposits by the $\mathrm{TL}_{\text {MAX }}$ method yielded the most relevant results (412-445 ka), which indicate that these deposits were formed during the end of the MIS 12 and beginning of the MIS 11 stage.
\end{abstract}

Key words: chronostratigraphy, geochronology, interglacial meandering river, Pleistocene, Mazovian/Holsteinian, eastern Poland.

\section{INTRODUCTION}

Interglacial fluvial deposits are important for Pleistocene stratigraphy. In Central-Eastern Europe, a region glaciated several times, the pre-Holocene fluvial deposits have been investigated in borehole cores only. Their stratigraphic position was determined by palaeobotanical analyses of biogenic and clastic deposits, their superposition on till units, and their ages determined by thermoluminescence dating of clastic deposits (e.g., Lindner et al., 1982; Krzyszkowski, 1992; Marks and Pavlovskaya, 2003; Albrycht, 2004). We regard such interpretation of interglacial origin as incomplete if facies analysis is lacking. Unconsolidated deposits sampled from borehole cores cannot be studied sedimentologically.

The aim of this paper is to describe fluvial deposits and to determine their stratigraphic position, focussing on a unique, near-surface deposit of a meandering river in the Samica valley near Łuków in eastern Poland. This is the first report of these deposits. The following methods were used: (1) lithofacies analysis of the fluvial succession, (2) petrographic analysis of till from the till plain dissected by the palaeo-river, (3) palaeobotanical (pollen and plant macrofossil) analyses of biogenic oxbow lake deposits, and (4) luminescence dating of clastic channel deposits.

The questions addressed in this paper are: (1) Which lithological features can be regarded as indicators of interglacial fluvial deposition? (2) Can the petrographic character of till be used to determine the stratigraphic position of fluvial deposits incised into the till plain? (3) Which palaeobotanical features of biogenic oxbow lake facies may be used to recognise its stratigraphic position? (4) Which thermoluminescence method is most useful for absolute dating of the fluvial deposits?

\section{SITE INVESTIGATED}

*Corresponding author, e-mail: terpis@poczta.umcs.lublin.pl

** Deceased

Received: June 10, 2013; accepted: December 23, 2013; first published online: March 25, 2014
The Pleistocene surface succession of the Łuków region is traditionally classified as the youngest deposits of the Middle 


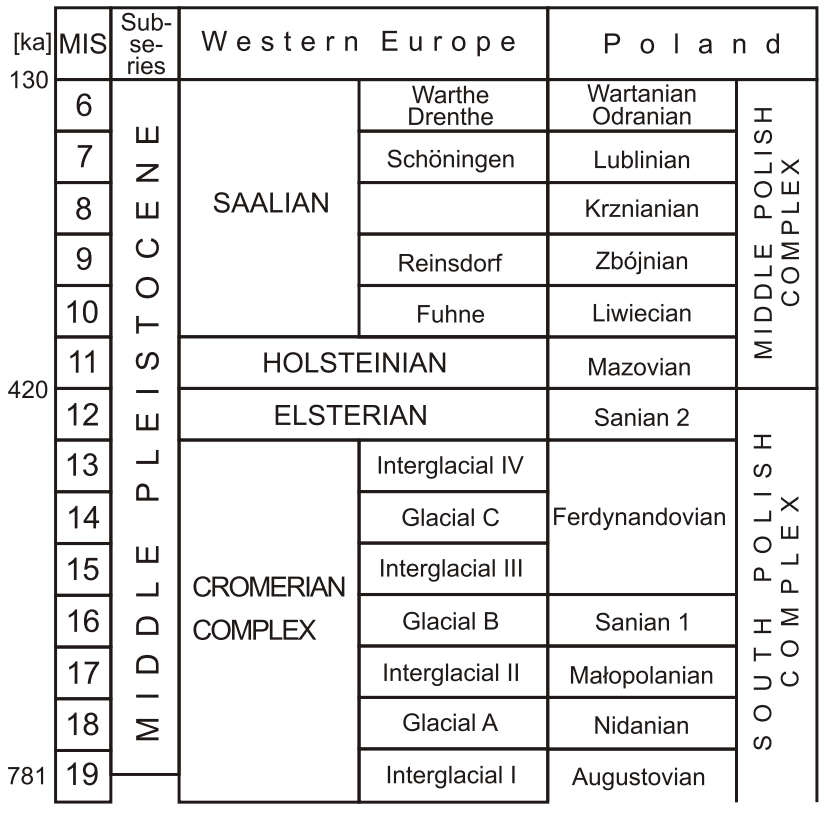

Fig. 1. Correlation of glaciations and interglacials in Poland (Ber et al., 2007) with their equivalents in Western Europe (Cohen and Gibbard, 2010)

Polish Complex: the Odranian Glaciation and Wartanian Stadial (cf. Terpiłowski, 2001; Małek, 2004; Małek and Buczek, 2009; Lindner and Marks, 2012), which are analogues of the Drenthe and Warthe units of the late Saalian of Western Europe (Fig. 1). The Wartanian Stadial ice-sheet limit is the boundary between two areas of distinctly different geomorphology (Fig. 2). The northern area is a morphologically and lithologically diverse marginal zone of the Wartanian Stadial ice sheet, formed by proximal outwash, eskers and kames. The southern area is a large outwash plain of the Wartanian Stadial ice sheet. It passes into the valley outwash trains of the upper reaches of the Krzna River and Bystrzyca Północna River with its main tributary - the Samica River. These outwash deposits fill the valleys, which cut into the flat till plain of the Odranian Glaciation.

The fluvial deposits investigated (unit C) of the Samica River (Kolonia Domaszewska site) fill the fossil valley incised both into till (unit $A$ ) and outwash gravelly sands (unit B). Fluvial unit $C$ is locally overlain by redeposited glacial deposits (unit $D$ ) (Figs. 2B and 3). The complete fluvial succession (unit C) is as follows: sands and gravels $\rightarrow$ sands and silts (subunit $\mathrm{C}-1$ ) $\rightarrow$ organic and mineral deposits (subunit C-2; Fig. 3).

\section{MATERIAL AND METHODS}

\section{SEDIMENTOLOGICAL ANALYSIS}

Deposits of all Pleistocene units (A-D, Fig. 3) were investigated using sedimentological analysis. Units A, B, D and subunit C-1 were studied in the field. Subunit C-2 was studied from undeformed core obtained using an Eijkelkamp corer. The texture and structure of all units were analysed, together with the thickness, shape and extent of depositional bodies (lithofacies) and contacts between them. Lithofacies were labeled using Miall (1978) and Krüger and Kjær (1999) codes with some modifications (Zieliński and Pisarska-Jamroży, 2012; Table 1). The orientations (dips and dip directions) of beds and cross-laminae were measured to infer palaeochannel morphology and flow direction, while orientations of the longest gravel axes were used to interpret the till origin and direction of ice-sheet advance. Ductile and brittle deformation structures were noted and their dimensions and orientations measured.

\section{PETROGRAPHIC ANALYSIS}

Petrographic analysis was carried out only for the basal till (unit A) of the till plain (Figs. 2B, 3 and $4, \log 1$ ). This method is commonly used to analyse indicator erratics in Germany and Poland and to identify their source areas (e.g., Meyer, 1983; Vinx et al., 1997; Hoffmann and Meyer, 1999; Czubla, 2001, 2006; Lüttig, 2005; Górska, 2006; Górska-Zabielska, 2008; Czubla et al., 2010a, b). A sample containing approximately 1000 clasts of the coarse gravel fraction (>20 mm in diameter) was extracted from a till-bed exposed in the pit. Indicator rocks of precisely identified Fennoscandian provenance were separated and analysed using Lüttig's method (1958), modified by Vinx et al. (1997) and Czubla (2001). Each indicator rock was assigned with geographical coordinates of the mid-point of its source area in Fennoscandia, and these (altitudes and longitudes separately) were added and averaged. The result was a geographical location of the mid-point of the source areas of indicator rocks in the till-bed studied - the Theoretical Boulder Centre (TBC; Lüttig, 1958), permitting individual samples extracted from glacial deposits to be compared. Based on crystalline (igneous and metamorphic) erratics only to avoid the effect of elimination of less resistant sedimentary rocks, the TBC was calculated and compared with the TBCs assigned for tills in the South Podlasie Lowland. The proportions of different rock groups were determined and, following the procedure de-

Table 1

Lithofacies code symbols used in this study

\begin{tabular}{|c|c|}
\hline Code & Description \\
\hline \multicolumn{2}{|r|}{ Texture } \\
\hline$T$ & silts \\
\hline ST & silty sands \\
\hline S & sands \\
\hline SG & gravelly sands \\
\hline G & gravels \\
\hline GS & sandy gravels \\
\hline GSD & diamictic sandy gravels \\
\hline $\mathrm{D}$ & diamicton (till) \\
\hline DS & sandy diamicton \\
\hline C & organic or organic-clastic deposits (peats, gyttja) \\
\hline \multicolumn{2}{|r|}{ Structure } \\
\hline $\mathrm{m}$ & massive \\
\hline$\left(m_{1}\right)$ & matrix-supported, gravels content $<15 \%$ (for till only) \\
\hline $\mathrm{h}$ & horizontal lamination/stratification \\
\hline $\mathrm{r}$ & ripple cross-lamination \\
\hline$f$ & flaser lamination \\
\hline $\mathrm{t}$ & trough cross-stratification \\
\hline I & low-angle cross-stratification \\
\hline $\mathrm{x}$ & cross lamination/stratification (in general) \\
\hline $\mathrm{e}$ & erosional scour fill \\
\hline $\mathrm{s}$ & stratified (for diamicton only) \\
\hline$d$ & deformed \\
\hline
\end{tabular}




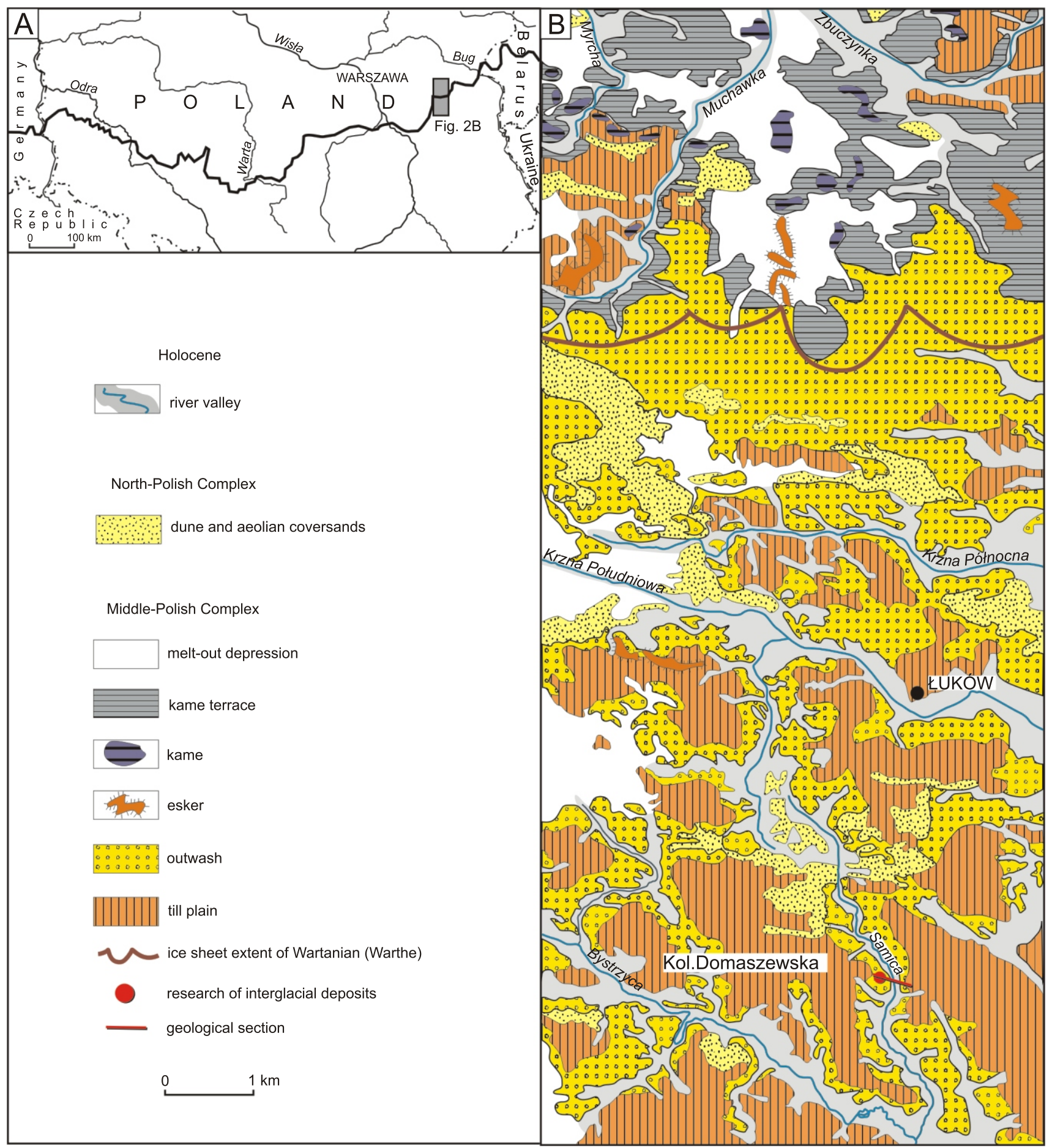

Fig. 2. The Łuków area

A - location in the context of the ice-sheet maximum extent of the Wartanian/Warthe Stadial of the Odranian/Drenthe Glaciation (after Marks, 2004); B - geomorphological sketch (according to Terpiłowski, 2001; Małek, 2004; Małek and Buczek, 2009)

scribed by Smed (1993), a map of the distribution of indicator erratics was drawn.

PALAEOBOTANICAL ANALYSES

Palaeobotanical analyses included pollen analysis and plant macrofossil analysis. They were based on the core (SO1) taken from a depth interval of 1.05-3.65 m using an Eijkelkamp corer (subunit C-2; Figs. 5 and 6). The core was sampled and analysed every $5-10 \mathrm{~cm}$, depending on changes in pollen spectra.

POLLEN ANALYSIS

Material for pollen analysis was obtained using hydrofluoric acid method. Samples were treated with $10 \% \mathrm{HCl}$ to remove carbonates, then boiled with $3.5 \% \mathrm{KOH}$. The mineral fraction was removed using $40 \% \mathrm{HF}$. The organic fraction was subjected to 


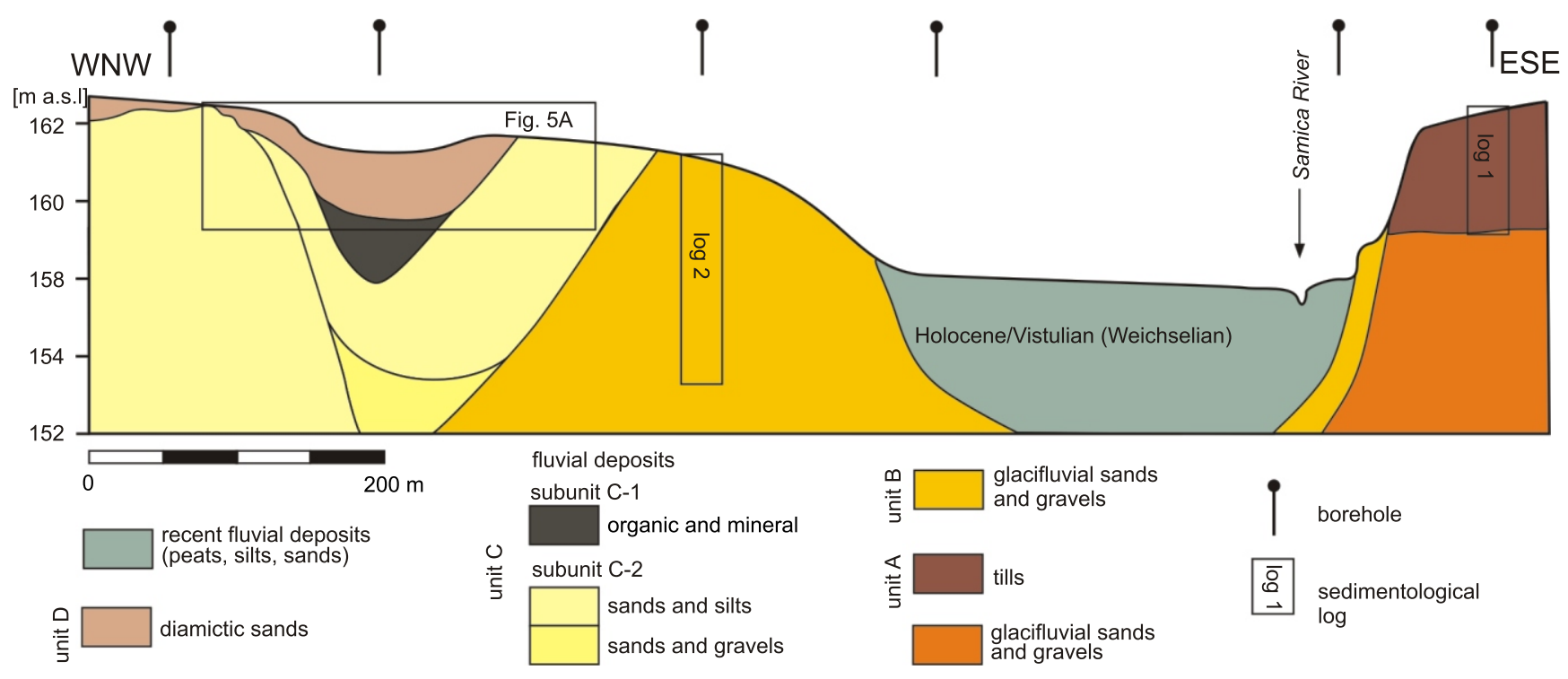

Fig. 3. Schematic cross-section through the Samica River valley in the Kolonia Domaszewska

For location see Figure 2

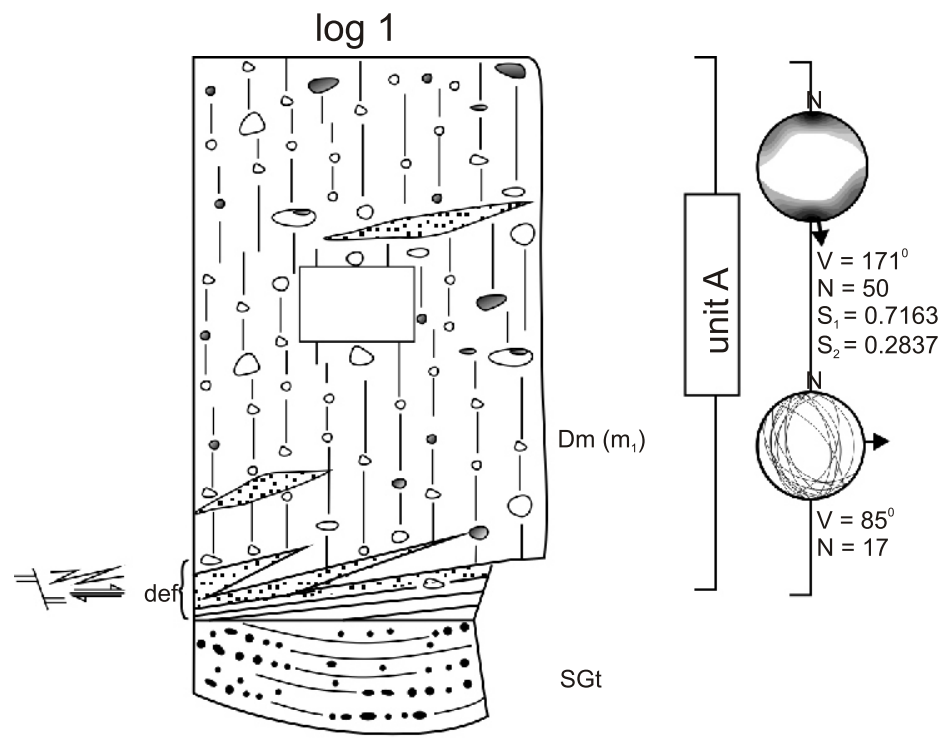

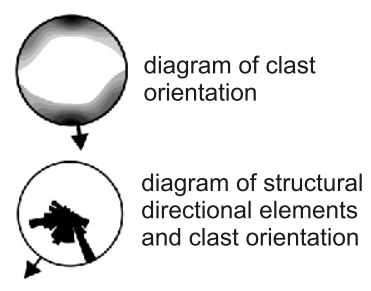

2 rooted structure

$\rightleftharpoons \quad$ shear plane

$\Rightarrow$ fault

def

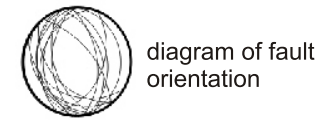

$\mathrm{V}$ mean azimuth

$\mathrm{N}$ number of readings

$\mathrm{S}_{1}, \mathrm{~S}_{2}$ Eigenvalues

(R) reactivation

Sh lithofacies

$\square$ place of sampling $\log 2$
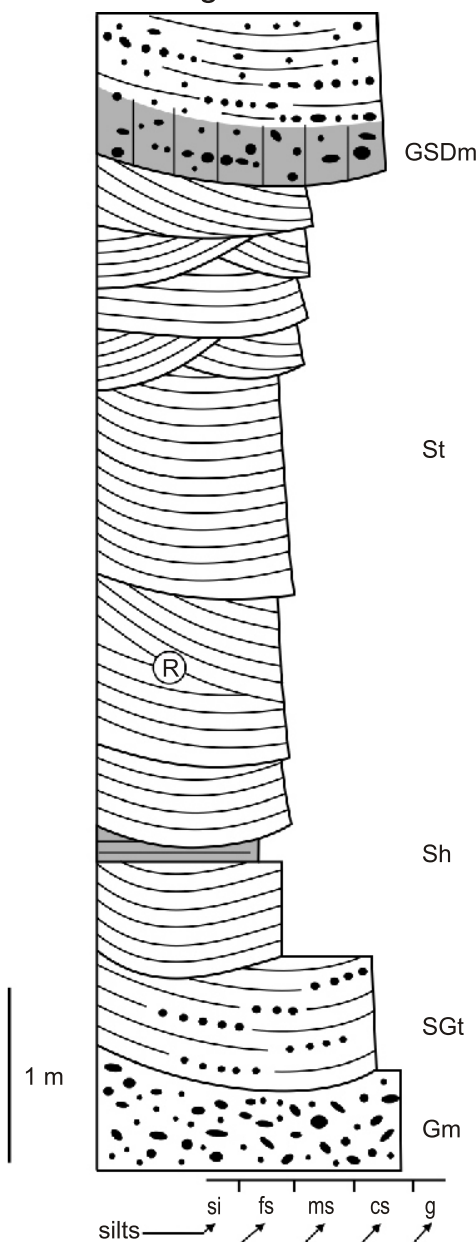

fine-grained sands medium-grained sands

coarse-grained sands
gravels
St

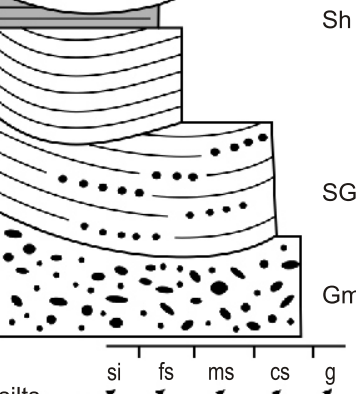

GSDm

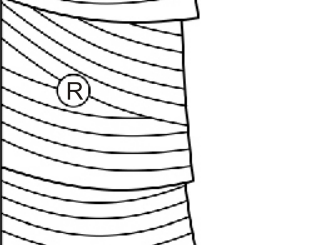

Sh

Fig. 4. Sedimentary logs of units A and B in the Kolonia Domaszewska

For their location see Figure 3; for lithofacies symbols see Table 1 


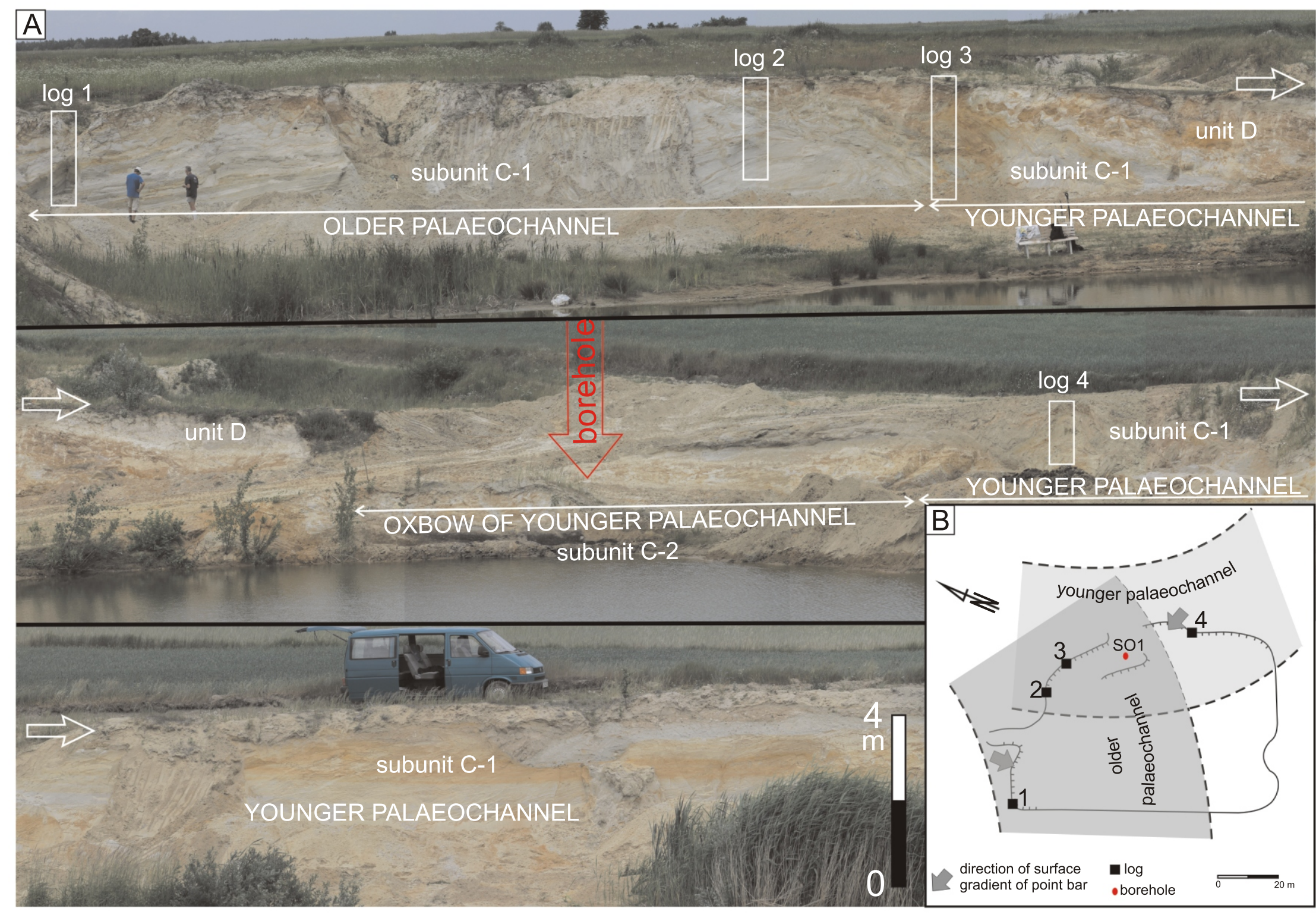

Fig. 5. Fluvial deposits of the fossil Samica River valley in the Kolonia Domaszewska 


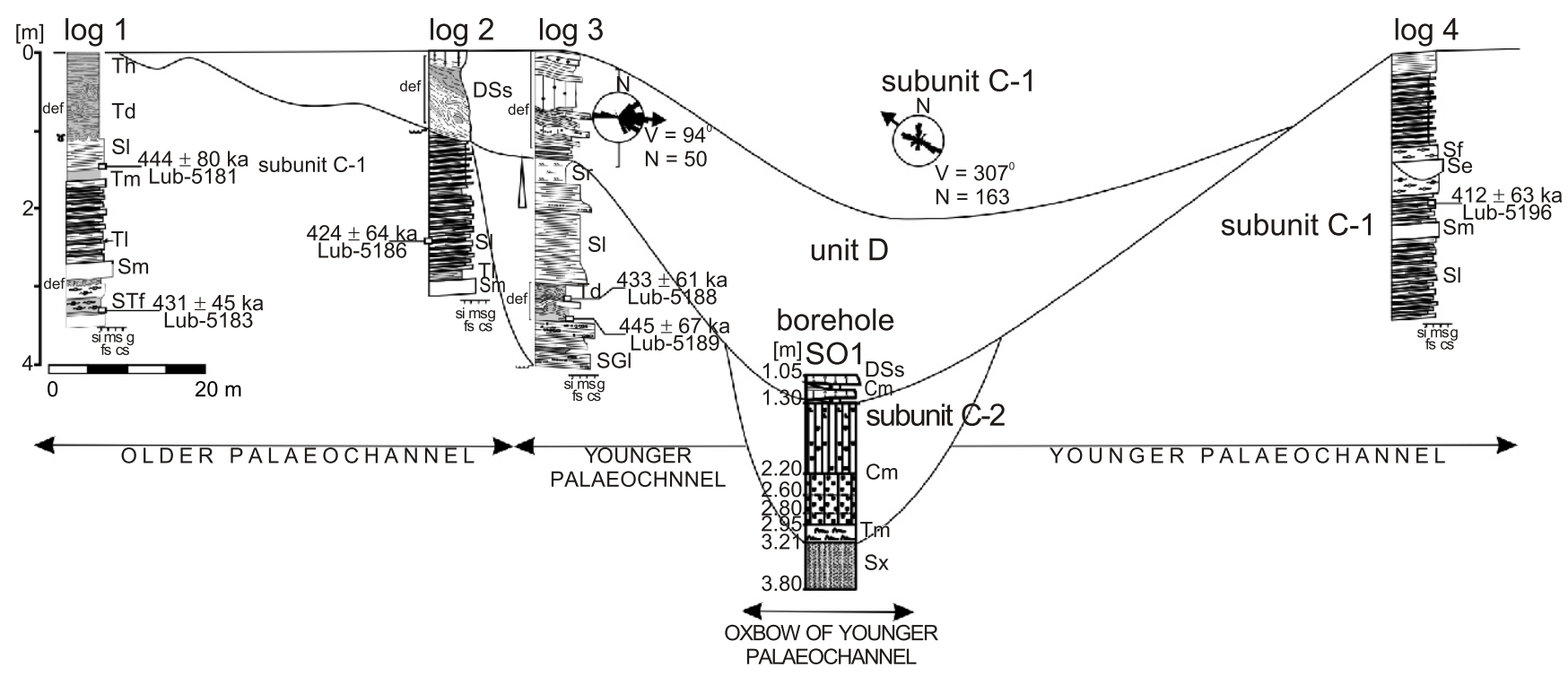

Fig. 6. Sedimentary logs of the fluvial units in the Kolonia Domaszewska

For their location and explanations see Figures 4 and 5; for lithofacies symbols see Table 1

Erdtman's acetolysis, the sporomorphs obtained were stained with acid fuchsine and washed with pure glycerine. Pollen spectra were counted on at least two slides. Usually 600-900 pollen grains of trees and shrubs (AP) were counted in samples with good frequency of sporomorphs. In samples with few sporomorphs - at least $300-400$ grains of AP+NAP were counted. The results of pollen analysis of 33 samples are shown in a percentage diagram, prepared using POLPAL software (Nalepka and Walanus, 2003). The calculations of pollen and spore percentages were based on the sum of pollen grains of trees and shrubs (AP) and of terrestrial herbs and dwarf shrubs (NAP). The percentages of aquatic and lakeshore vegetation pollen of Pteridophyta and Bryophyta spores, algae, redeposited and non-determined taxa were calculated in relation to the sum $\mathrm{AP}+\mathrm{NAP}+$ given taxon. The pollen succession is divided into local pollen assemblage zones (LPAZs) distinguished using criteria published by West (1970) and Janczyk-Kopikowa (1987). The names of the zones are derived from these taxa, which are predominant in or typical of a particular zone.

\section{PLANT MACROFOSSIL ANALYSIS}

Samples for analysis of plant macroremains (29 samples) were taken in correlation with ones used for pollen analysis. All samples were subjected to maceration using a $10 \%$ solution of $\mathrm{KOH}$ and detergents. $150 \mathrm{ml}$ of sediment was soaked in water for ca. 24 hours and then boiled with $\mathrm{KOH}$ added. After the sediment was boiled to a pulp, the samples underwent wet sieve analysis using a $0.2 \mathrm{~mm}$ mesh sieve. The material remaining on the sieve was sorted under a magnifying glass. All plant remains qualifying for identification were isolated and placed in a mixture of glycerine, water and ethyl alcohol in ratio of 1:1:1, with thymol added. The material was stored in separate small "boxes". The isolated plant remains were determined to species level, as far as was possible, considering the condition of the preserved material (cf. Hrynowiecka and Szymczyk, 2011; Stachowicz-Rybka, 2011). Samples from depths of 105, 120, $125 \mathrm{~cm}$ and $140-145 \mathrm{~cm}$, were barren or contained only single unidentifiable fragments of plant tissues. The plant macroremains determined were included into local macrofossil assemblage zones (LMAZs) and correlated with LPAZs.

\section{LUMINESCENCE DATING}

The luminescence age of deposit is given by the ratio of the equivalent dose to the dose rate. The equivalent dose is defined as the irradiation dose absorbed by a sample in the laboratory, assuming that its luminescence intensity is the same as in natural conditions. The dose rate is defined as the energy of ionizing radiation absorbed by a sample in a unit of time (year, millennium).

The age of six sandy-silty samples derived from point-bar facies (subunit C-1; for their location see Figs. 5 and 6 ) was estimated by thermoluminescence (TL). Although this method is not thought to provide good results for deposits older than 300-400 ka (Frechen et al., 1999; Bluszcz, 2000), we use it because some studies (Berger et al., 1992; Łanczont et al., 2011; Kusiak et al., 2013) show that it is possible to accurately date deposits up to 500-800 ka. For control, two samples from log 1 were dated by infrared light stimulated luminescence (IRSL), which allows dating of deposits up to 300 ka (e.g., Yi et al., 2012).

Material for analysis was prepared and measurements carried out in a room lit with Kaiser Spectral 590 lamps. In order to determine the equivalent dose (ED) the $45-56 \mu \mathrm{m}$ polymineral fraction was separated by wet sieving, the mineral material being treated with $10 \% \mathrm{HCl}$ and $30 \% \mathrm{H}_{2} \mathrm{O}_{2}$.

For TL dating the mineral grains were irradiated with a ${ }^{60} \mathrm{Co}$ $\gamma$ source to $5000 \mathrm{~Gy}$ in the Institute of Nuclear Chemistry and Technology in Warsaw. After irradiation the samples were stored for three months. Before the TL measurements they were preheated at $160^{\circ} \mathrm{C}$ for 3 hours, the glow curves being recorded using a $R A^{\prime}$ '94 thermoluminescence one-position reader (produced by Mikrolab Kraków, Poland) with an EMI 9789 QA photomultiplier. A BG-28 optical filter (380-500 nm) was used 
Table 2

Description of the pIRIR 290 and MET-pIRIR dating procedures of the IRSL method (Thiel et al., 2011; Li and Li, 2011)

\begin{tabular}{|c|c|c|c|c|c|}
\hline \multicolumn{3}{|c|}{ pIRIR $_{290}$} & \multicolumn{3}{|c|}{ MET-pIRIR } \\
\hline Step & Treatment & Observed & Step & Treatment & Observed \\
\hline $\begin{array}{l}1 \\
2 \\
3 \\
4 \\
5 \\
6 \\
7 \\
8 \\
9 \\
10\end{array}$ & $\begin{array}{c}\text { Given dose, } D_{i} \\
\text { Preheat, } 320^{\circ} \mathrm{C} \text { for } 60 \mathrm{~s} \\
\text { IRSL measurement, } 200 \mathrm{~s} \text { at } 50^{\circ} \mathrm{C} \\
\text { IRSL measurement, } 200 \mathrm{~s} \text { at } 290^{\circ} \mathrm{C} \\
\text { Give test dose, } D_{T} \\
\text { Preheat, } 320^{\circ} \mathrm{C} \text { for } 60 \mathrm{~s} \\
\text { IRSL measurement, } 200 \mathrm{~s} \text { at } 50^{\circ} \mathrm{C} \\
\text { IRSL measurement, } 200 \mathrm{~s} \text { at } 290^{\circ} \mathrm{C} \\
\text { IRSL measurement, } 100 \mathrm{~s} \text { at } 325^{\circ} \mathrm{C} \\
\text { Return to } 1\end{array}$ & $\begin{array}{l}\mathrm{L}_{x} \\
\mathrm{~L}_{\mathrm{x}}\end{array}$ & $\begin{array}{l}1 \\
2 \\
3 \\
4 \\
5 \\
6 \\
7 \\
8 \\
9 \\
10 \\
11 \\
12 \\
13 \\
14 \\
15 \\
16 \\
17 \\
18\end{array}$ & $\begin{array}{c}\text { Given dose, } D_{i} \\
\text { Preheat, } 320^{\circ} \mathrm{C} \text { for } 60 \mathrm{~s} \\
\text { IRSL measurement, } 100 \mathrm{~s} \text { at } 50^{\circ} \mathrm{C} \\
\text { IRSL measurement, } 100 \mathrm{~s} \text { at } 100^{\circ} \mathrm{C} \\
\text { IRSL measurement, } 100 \mathrm{~s} \text { at } 150^{\circ} \mathrm{C} \\
\text { IRSL measurement, } 100 \mathrm{~s} \text { at } 200^{\circ} \mathrm{C} \\
\text { IRSL measurement, } 100 \mathrm{~s} \text { at } 250^{\circ} \mathrm{C} \\
\text { IRSL measurement, } 100 \mathrm{~s} \text { at } 300^{\circ} \mathrm{C} \\
\text { Give test dose, } D_{T} \\
\text { Preheat, } 320^{\circ} \mathrm{C} \text { for } 60 \mathrm{~s} \\
\text { IRSL measurement, } 100 \mathrm{~s} \text { at } 50^{\circ} \mathrm{C} \\
\text { IRSL measurement, } 100 \mathrm{~s} \text { at } 100^{\circ} \mathrm{C} \\
\text { IRSL measurement, } 100 \mathrm{~s} \text { at } 150^{\circ} \mathrm{C} \\
\text { IRSL measurement, } 100 \mathrm{~s} \text { at } 200^{\circ} \mathrm{C} \\
\text { IRSL measurement, } 100 \mathrm{~s} \text { at } 250^{\circ} \mathrm{C} \\
\text { IRSL measurement, } 100 \mathrm{~s} \text { at } 300^{\circ} \mathrm{C} \\
\text { IRSL measurement, } 100 \mathrm{~s} \text { at } 325^{\circ} \mathrm{C} \\
\text { Return to } 1\end{array}$ & $\begin{array}{l}\mathrm{L}_{\times 50} \\
\mathrm{~L}_{\times 100} \\
\mathrm{~L}_{\times 150} \\
\mathrm{~L}_{\times 200} \\
\mathrm{~L}_{\times 250} \\
\mathrm{~L}_{\times 300} \\
\mathrm{~T}_{\mathrm{x} 50} \\
\mathrm{~T}_{x 100} \\
\mathrm{~T}_{\mathrm{x} 150} \\
\mathrm{~T}_{\mathrm{x} 200} \\
\mathrm{~T}_{\mathrm{x} 250} \\
\mathrm{~T}_{\mathrm{x} 300}\end{array}$ \\
\hline
\end{tabular}

(Berger et al., 1992). The samples were heated up to $400^{\circ} \mathrm{C}$ at the rate of $10^{\circ} \mathrm{C} / \mathrm{sec}$ in an argon atmosphere. To determine the equivalent dose the total-bleach technique was used. Luminescence intensity was determined in two different ways. Two regions under the glow curve were established at the light sum: (1) the $10^{\circ} \mathrm{C}$ wide region of the glow peak ( $T L_{\text {MAX }}$ ) (Kusiak, 2008; Łanczont et al., 2011; Kusiak et al., 2013), (2) the $100^{\circ} \mathrm{C}$ wide region $\left(270-370^{\circ} \mathrm{C} ; \mathrm{TL}_{\mathrm{INT}}\right)$ containing the glow peak (Frechen, 1992). The plateau test was carried out; for all samples the glow peak occurred within the plateau.

IRSL measurements were made following the single aliquot regeneration (SAR) procedure (Murray and Wintle, 2000; Wallinga et al., 2000). The Risø TL-DA-20 automatic reader was used with the filter set (320-480 nm): Schott BG-39 and Corning 7-59. Table 2 describes the two dating procedures: pIRIR 290 - luminescence reading at a temperature of $50^{\circ} \mathrm{C}$ and then at $290^{\circ} \mathrm{C}$ (Thiel et al., 2011) and MET-pIRIR - luminescence reading at a temperature of $50^{\circ} \mathrm{C}$, and every $50^{\circ} \mathrm{C}$ up to $300^{\circ} \mathrm{C}$ (Li and Li, 2011).

The dose rate was determined by means of gamma spectroscopy. Stationary spectrometers Mazar-01 and Mazar-95 with scintillation probes (produced by Polon-Izot Milanówek, Poland) and containers of Marinelli type with a volume of $470 \mathrm{~cm}^{3}$ were used. The measurement time for one sample was $80,000 \mathrm{~s}$. Corrections were made for cosmic radiation (Prescott and Hutton, 1994) and for deposit moisture at the
$18 \%$ level (Berger, 1988). The efficiency factor of alpha radiation in luminescence inducing was used (Benea et al., 2007). The concentrations of radioisotopes were converted into absorbed dose rates for $\alpha, \beta$ and $\gamma$ radiation, based on data published by Adamiec and Aitken (1998; Table 3).

\section{RESULTS}

\section{SEDIMENTOLOGICAL ANALYSIS}

UNIT A

Unit $A$ is $3 \mathrm{~m}$ thick and built the eastern slope of the Samica River valley (Figs. 2B and 3). Massive diamicton - lithofacies $\operatorname{Dm}\left(m_{1}\right)$ - contains a few elongated sandy clasts and rare gravels dispersed within the matrix (Fig. 4, log 1). Gravel fabric is very good $\left(S_{1}=0.7163\right)$. The directional distribution is symmetrical, with a distinct $\mathrm{N}-\mathrm{S}$ mode $\left(\right.$ mean vector $=171^{\circ}$ ). The basal contact with sandy-gravelly glaciofluvial deposits is partly deformational. Some wedges filled with the diamicton are bordered by shear planes (normal faults and flexures). Their strike is $\mathrm{W}-\mathrm{E}$ (mean vector $=85^{\circ}$ ), i.e. transverse to the orientation of elongated gravels within the diamicton.

Diamicton of unit A displays features typical of basal till of lodgement type (Dreimanis, 1989). The massive structure,

Concentrations of radioisotopes $(K, U, T h)$ and values of dose rate $\left(D_{r}\right)$

\begin{tabular}{|l|c|c|c|c|r|c|}
\hline Sample & $\begin{array}{c}\text { Depth } \\
{[\mathrm{m}]}\end{array}$ & $\begin{array}{c}\text { Sample No. } \\
\text { Lub- }\end{array}$ & $\begin{array}{c}\mathrm{K} \\
{[\mathrm{Bq} / \mathrm{kg}]}\end{array}$ & $\begin{array}{c}\mathrm{U} \\
{[\mathrm{Bq} / \mathrm{kg}]}\end{array}$ & $\begin{array}{c}\mathrm{Th} \\
{[\mathrm{Bq} / \mathrm{kg}]}\end{array}$ & $\begin{array}{c}\text { Dose rate } \\
D_{r} \\
{[\mathrm{~Gy} / \mathrm{ka}]}\end{array}$ \\
\hline SPB-1 & 1.4 & 5181 & $362 \pm 16$ & $21.6 \pm 1.9$ & $25.3 \pm 1.3$ & $2.49 \pm 0.12$ \\
SPB-2 & 3.4 & 5183 & $351 \pm 18$ & $31.9 \pm 2.9$ & $26.5 \pm 1.4$ & $2.78 \pm 0.14$ \\
SPB-3 & 2.4 & 5186 & $250 \pm 13$ & $15.1 \pm 1.4$ & $19.3 \pm 1.1$ & $1.90 \pm 0.15$ \\
SPB-4 & 3.2 & 5188 & $387 \pm 17$ & $28.1 \pm 2.5$ & $30.9 \pm 1.5$ & $2.90 \pm 0.15$ \\
SPB-5 & 3.4 & 5189 & $395 \pm 21$ & $41.8 \pm 3.1$ & $28.6 \pm 1.4$ & $3.39 \pm 0.16$ \\
SPB-6 & 2.0 & 5196 & $116 \pm 6$ & $10.8 \pm 1.0$ & $6.7 \pm 0.4$ & $1.02 \pm 0.09$ \\
\hline
\end{tabular}


deformational contact with underlying glaciofluvial deposits, and character of deformational structures derived from simultaneous lodgement and shearing along an ice-sheet sole (cf. Boulton and Hindmarsh, 1987; Hart and Boulton, 1991; Van der Meer et al., 2003). The well-developed gravel fabric together with transverse orientation of deformational structures support this genetic interpretation. These indicate ice-sheet advance from the North.

\section{UNIT B}

Deposits of unit B form a $600-800 \mathrm{~m}$ wide tract, oriented NNW-SSE (Figs. 2 and 3). It is the oldest terrace level in the present-day Samica River valley. Fine-grained sands with sandy-gravelly intrabeds prevail in unit B (Fig. 4, log 2). Trough cross-stratification (lithofacies St, SGt), mainly of large scale, is the most common depositional structure. The largest troughs (deeper than $1 \mathrm{~m}$ and longer than $10 \mathrm{~m}$ ) usually contain the compound infill. In places the cosets of cross-laminae are divided by reactivation surfaces. In other cases, the structure changes within the sandy infill: low-angle cross-stratification (lithofacies $\mathrm{SI}$ ) is overlain by horizontal stratification (lithofacies $\mathrm{Sh})$. The lower part of the trough is filled with sandy-clayey (diamictic) gravel with massive structure (lithofacies GSDm), whereas the upper part is made up of cross-stratified gravelly sand (lithofacies SGt). The beds of massive sand (lithofacies $\mathrm{Sm}$ ) and gravel (lithofacies $\mathrm{Gm}$ ), $40-50 \mathrm{~cm}$ thick, are a secondary lithofacies in unit B. In the upper part an ice-wedge cast $70 \mathrm{~cm}$ long was found.

We interpret unit B as the sedimentary record of a valley sandur - elongated outwash confined by valley slopes. It derived from the retreat of the ice sheet which formed the surrounding till plain. Lateral shifting as well as extensive aggradation of braided channels were inhibited in this confined fluvial environment. Therefore the channel bed underwent frequent erosion and abundant troughs were formed. The trough cross-stratified beds St thinner than $0.5 \mathrm{~m}$ were linked with processes of local erosion and deposition in separation zones located distally to the three-dimensional dunes. The larger troughs are interpreted as the record of pools in the central areas of high-energy channels (Siegenthaler and Huggenberger, 1993; Marren et al., 2009). Their filling with sediment took place in a few phases, most probably during successive floods (see Olsen and Andreasen, 1995). Reactivation surfaces indicate frequent, short-term pulses of meltwater discharge. Vertical successions $\mathrm{SI} \rightarrow \mathrm{Sh}$ within large-scale troughs prove the deposition from transitional and supercritical currents which were generated by high flow velocity. Diamictic gravels at the base of some compound infills suggest that powerful ablation floods (with erosion of pools) were connected with flow-till surges which underwent initial fluvial redeposition (deposition of GSDm lithofacies; Pisarska-Jamroży and Zieliński, 2014). This lithofacies is evidence for ice-sheet margin proximity (cf. Aitken, 1998). The beds of massive sand and gravel derived from abrupt aggradation are thought to represent the first phases of waning floods. Directional data of cross-beds show that proglacial meltwaters flowed towards the SSW (mean azimuth $=218^{\circ}$ ). Palaeocurrent distribution covers $180^{\circ}$ with three main modes (towards the SSW, SSE and ESE) which reflect orientation of channels within a braided system. Lithofacies association St, Gt, Sh, generally similar to the studied unit B, has been found by Dobracki and Krzyszkowski (1997) in proximal Pleistocene outwash in NW Poland.

$$
\text { UNIT C }
$$

This is the main package of deposits investigated because it contains organic beds and an interglacial origin is inferred. It includes two fluvial subunits derived from: an active channel (subunit C-1) and an oxbow lake (subunit C-2; Figs. 3 and 5).

Subunit C-1. This subunit is composed of sand, silty sand and silt (commonly occurring as rhythmites), with subordinate gravelly sand (Figs. 5 and 6). These deposits fill two stacked palaeochannels $50-70 \mathrm{~m}$ wide and up to $8 \mathrm{~m}$ deep. The upper palaeochannel is partly incised in the lower one. The packages of sand beds are characterized by low-angle $\left(<15^{\circ}\right)$ uniform dip (lithofacies SI), transverse to the palaeochannel axes. Inclined parallel lamination predominates in the beds but there is also massive structure as well as planar cross-stratification where laminae dip opposite to the bed inclination. Therefore, these are packages of epsilon cross-stratification (ESC) type derived from point bars. Parallel, inclined lamination in sand is a record of deposition on the point-bar platform which gently sloped towards the thalweg. Sandy-silt beds within inclined beds (lithofacies STI) typically show parallel lamination, but flaser lamination has been also noted. The frequency of sandy-silt and silt components increases towards the tops of palaeochannel infills. Fining-up successions $30-70 \mathrm{~cm}$ thick are present within palaeochannel infills. They start from erosively-based coarse sand with granules (lithofacies SGI or SGp lithofacies) overlain by fine sand with parallel lamination (lithofacies $\mathrm{SI}$ ) and then by laminated sandy silt (lithofacies TSh or TSI).

Channel deposits arranged in epsilon cross-stratification (ESC) indicate that palaeochannels were highly sinuous; this was a typical meandering river with bends of small radius (Miall, 1996). In terms of fluvial facies models, the deposits studied are regarded as the sedimentary record of a low-energy meandering river, as the channel facies studied comprises an association of fine-grained sand beds together with silty ones, i.e. epsilon cross-stratification (ESC) can be identified in this case with inclined heterolithic stratification (IHS) sensu Thomas et al. (1987). Similar fine-grained deposits of highly sinuous alluvial channels have been reported by Edwards et al. (1983), Gibling and Rust (1987), Smith (1987) and Wood (1989). Another typical meandering-river feature of the succession studied is the presence of a thick (1 m or more) silty package capping the palaeochannel sedimentary profile (cf. Blakey and Gubitosa, 1984). Directional data of bedding and stratification/lamination is also an important tool in environmental interpretation. Generally, the river flowed to the NNE (mean vector $=327^{\circ}$ ), i.e. opposing to the previous outwash system (unit B). Dip azimuths show a spread of $360^{\circ}$ with polymodal distribution which is typical of highly sinuous (meandering) channels. The three main directions seen in the current rose diagram reflect primary channel directions: WWN and ESE represent point-bar lateral accretion, and $\mathrm{N}$ is connected with the main flow in the thalweg. All these features suggest a meandering river in a temperate climate.

Subunit C-2. The oxbow of the younger palaeochannel is filled with about $2 \mathrm{~m}$ of organic and clastic deposits (Figs. 5 and 6). The sedimentary succession is as follows: massive silt (lithofacies Tm) $\rightarrow$ massive organic deposits (lithofacies $\mathrm{Cm}$ ) gyttja with peat intercalations in the lower part, peat with gyttja intercalations in the upper part $\rightarrow$ sandy stratified diamicton (lithofacies DSs) with massive gyttja intrabeds (lithofacies $\mathrm{Cm}$ ) (Fig. 6). The lithologies and superposition of these members in subunit C-2 suggests deposition in an oligotrophic/mesotrophic lake which underwent progressive eutrophization and finally was filled with sediment of unit D.

UNIT D

In the transition zone between the palaeochannel and the till plain, the channel deposits are covered by a unit of sandy, stratified diamicton, which is up to $2 \mathrm{~m}$ thick in the axial part of the palaeochannel (Figs. 3 and 6). It consists of irregular, deformed beds of clayey sand and gravel with poor fabric (mean vector $=$ 


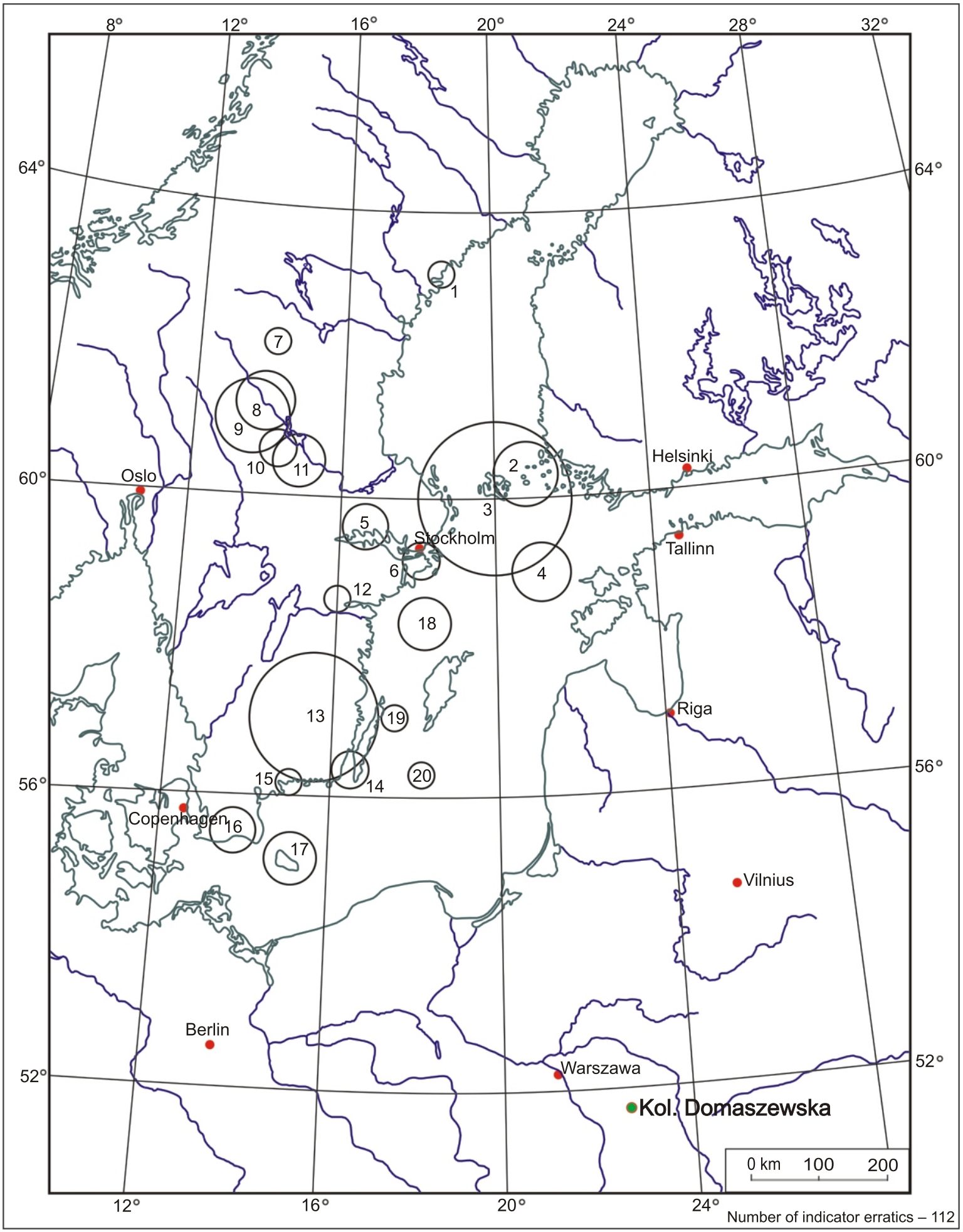

Fig. 7. Source areas of indicator erratics recognized in the Kolonia Domaszewska till

The circle's area corresponds to the percentage of erratics in an analysed stone sample; graphic presentation method (circle map) after Smed (1993): 1 - Ångermanland granite-gneiss; 2 - Åland and/or Nystad Pyterlite; 3 - Åland granite, Haga granite, Âland Rapakivi, Åland aplite granite, Åland granite porphyry; 4 - red Baltic quartz porphyry; 5 - Sala granite; 6 - Stockholm granite; 7 - Glöte porphyry; 8 - Åsen, Bredvad and Kåtilla porphyries, Garberg granite; 9 - Öje diabase and melaphyre, Dala sandstone, Digebergs sandstone and conglomerate; 10 - Venjan porphyry; 11 - Siljan granite, Siljan Rapakivi, Månsta porphyry; 12 - red and brown Graversfors granites, Östgöta granites; 13 - red Småland granites, Vislanda granite, Småland porphyries; 14 - Kalmarsund and Tessini sandstones; 15 - Karlshamn and Spinkamåla (Halen) granites; 16 - Kullaite, Scolithos and Hardeberga sandstones; 17 - Hammer and Vang granites, Bornholm gneisses; 18 - red Cambrian sandstones; 19 - red Ordovician limestones; 20 - Beyrichia limestone 


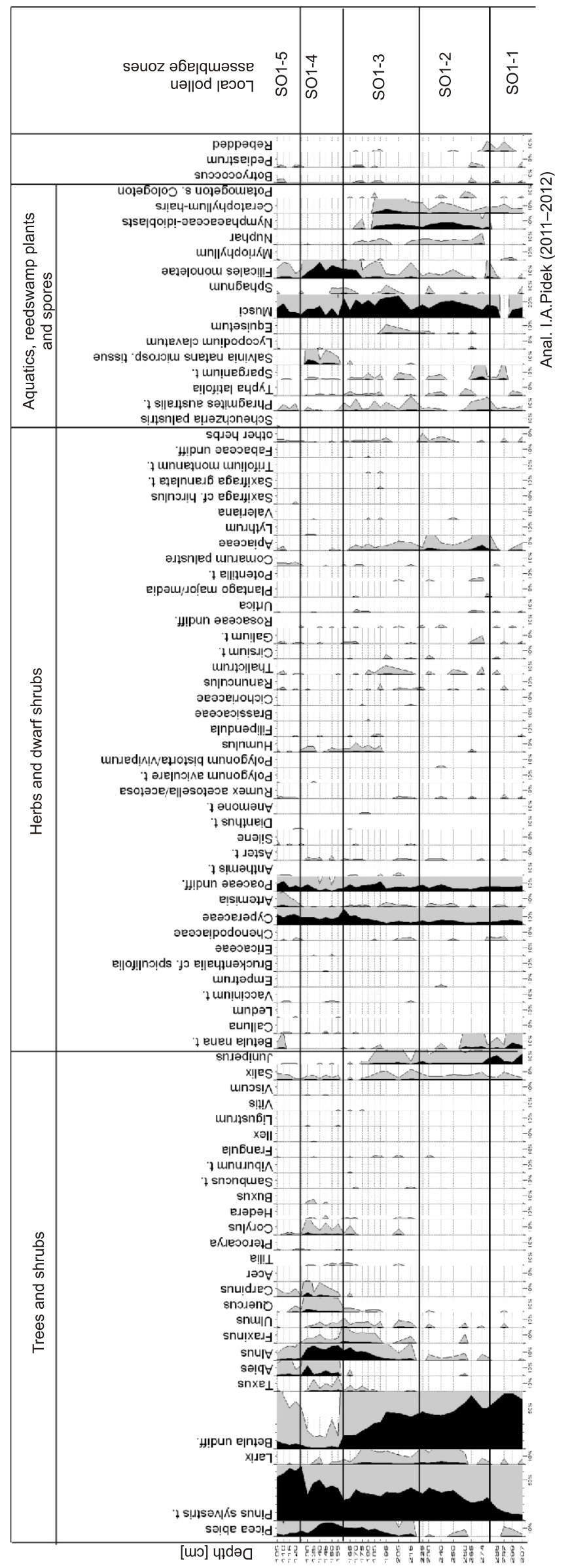

$\left.94^{\circ}\right)$. These alternate with discontinuous sand layers of crude stratification. Diamictic load casts (up to $1.5 \mathrm{~m}$ in amplitude), uniformly inclined folds and fractures with underlying fluvial sands are the most abundant deformation structures.

Such features are typical of slope solifluction deposits (Steijn et al., 1995). The orientations of elongated gravels suggests that massflow redeposition took place from the till plain bordering the fossil valley to the east.

\section{PETROGRAPHIC ANALYSIS}

Crystalline rocks $(64.78 \%)$ are predominant in the group of Fennoscandian rocks of the basal till. Among these, indicator erratics are quite common $-15.66 \%$. These are mostly rocks from Åland (43\%), Småland and Blekinge (26.9\%) and Dalarna (12.9\%; Fig. 7). The percentage of rocks from Uppland is very low $(6.4 \%)$. This indicates that the ice sheet was supplied with rock material which originated mostly from south-western Fennoscandia. This conclusion is supported by the low percentage of carbonate rocks $(15.51 \%)$ and the complete absence of dolomites in the Fennoscandian rock group. The high content of clastic rocks (as much as $18.97 \%$ ) is an additional indicator of this "western" source area because most of the Lower Paleozoic sandstone outcrops occur in the western part of the Baltic Depression and in Sweden.

The Theoretical Boulder Centre for the till in the site studied has the geographical coordinates $18.29^{\circ} \mathrm{E}$ and $59.13^{\circ} \mathrm{N}$. It is similar to that calculated for the lower basal tills occurring in central-eastern Poland (Czubla et al., 2010a, b). This position of the TBC is characteristic for the till of the San 2/Elsterian Glaciation, i.e. Marine Isotope Stage MIS 12 (see Fig. 1).

\section{PALAEOBOTANICAL ANALYSIS}

The results of pollen and plant macrofossil analyses are shown together. Pollen spectra inform mostly about terrestrial vegetation at local and regional scales, while plant macrofossils serve as the basis for reconstructing lake vegetation, and indirectly also inform about the lake trophic levels.

The pollen spectra belong to 5 local pollen assemblage zones (LPAZs; Fig. 8), and spectra of plant macrofossils to 5 local macrofossil assemblage zones (LMAZs; Fig. 9). LPAZs and LMAZs were designated with SO1 abbreviation and numbered from the base upwards. The lowermost samples of the succession investigated (from a depth of 310-365 cm) contained only sporadic sporomorphs so these were not shown in the pollen diagram. They contained macrofossils of dwarf birch (SO1-1 LMAZ - Betula nana, samples from $314-321 \mathrm{~cm}$ depth). The correlation of LPAZs and $L$ MAZs is given in Table 4.

S01-1 Betula-Juniperus-Betula nana LPAZ (samples from $286-307 \mathrm{~cm}$ depth) is characterized by the predominance of Betula undiff. pollen (60-68\%), gradually increasing pollen values of Pinus sylvestris t. (up to $15 \%$ in the upper sample of the zone), the occurrence of Picea, and sporadic pollen grains of Larix, Ulmus and Quercus. Among shrubs the pollen values of Juniperus are very high (up to $13.5 \%$ ), while Salix pollen is frequent. The continuous percentage curve of Betula 


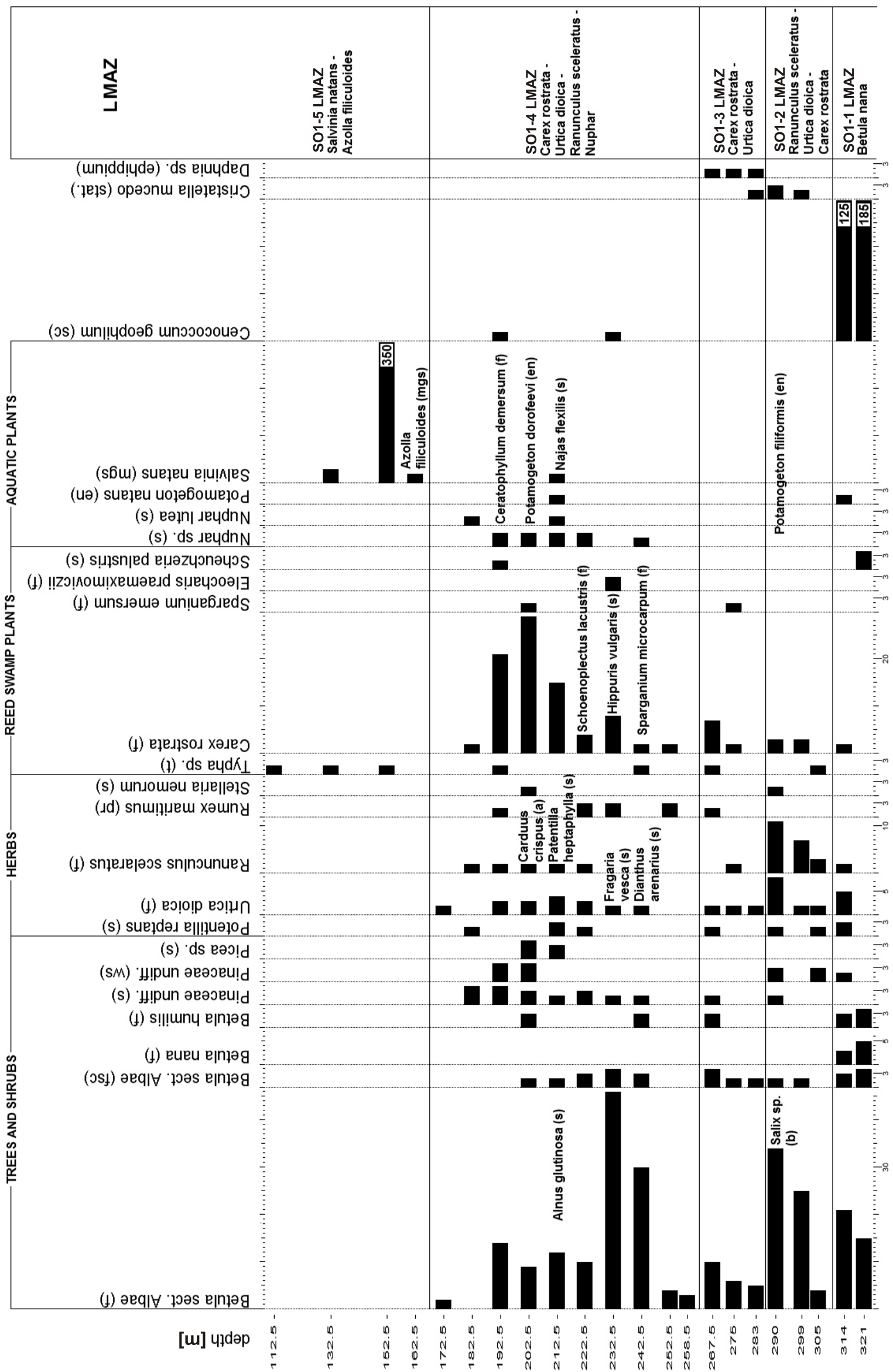


Correlation of pollen and macrofossil zones in the SO1 profile

\begin{tabular}{|c|c|c|}
\hline Local pollen assemblage zones & $\begin{array}{l}\text { Depth } \\
{[\mathrm{cm}]}\end{array}$ & Local macrofossil assemblage zones \\
\hline SO1-5 Pinus LPAZ & $105-128$ & \multirow[b]{2}{*}{ SO1-5 LMAZ Salvinia natans-Azolla filiculoides LMAZ } \\
\hline $\begin{array}{l}\text { SO1-4 Taxus-Quercus-Abies-/Carpinus/ } \\
\text { LPAZ }\end{array}$ & $128-158$ & \\
\hline SO1-3 Picea-Alnus-Fraxinus-/UImus/ LPAZ & $158-220$ & SO1-4 Carex rostrata-Urtica dioica-Ranunculus sceleratus-Nuphar LMAZ \\
\hline SO1-2 Pinus-Betula-Larix LPAZ & $220-283$ & SO1-3 Carex rostrata-Urtica dioica LMAZ \\
\hline SO1-1 Betula-Juniperus-Betula nana LPAZ & $286-307$ & SO1-2 Ranunculus sceleratus-Urtica dioica-Carex rostrata LMAZ \\
\hline Sporadic sporomorphs only & $307-365$ & SO1-1 Betula nana LMAZ \\
\hline
\end{tabular}

nana t. (up to $7.5 \%$ ) and high frequencies of Poaceae and Cyperaceae (up to $6.5 \%$ ) attract attention. The zone reflects the development of boreal, open birch forests at the beginning of the interglacial and is correlated with the SO1-2 LMAZ (Ranunculus sceleratus-Urtica dioica-Carex rostrata; samples from 290-305 cm depth). Macrofossils of Betula nana and B. humilis (fruits) indicate a cool climate. At first the catchment was overgrown by vegetation to a small extent, which favoured solifluction processes (many Cenococcum geophillum sclerotia). Salix (represented by boxes) grew on the shores of the lake, as well as plants typical of eutrophic alder carr habitats, i.e. Urtica dioica, Ranunculus sceleratus, Potentilla repens and Stellaria nemorum. The rush belt was formed by Carex rostrata and Typha (tegmens). The presence of Potamogeton filiformis (endocarps) in phytocoenoses indicates that the lake water was cool and mesotrophic (Kolstrup, 1979; Matuszkiewicz, 2001; Vielichkevich and Zastawniak, 2006). It was also very transparent, and contained $\mathrm{CaCO}_{3}$ (Bennike et al., 1994), as also indicated by the occurrence of numerous statoblasts of Cristatella mucedo (Økland and Økland, 2000).

SO1-2 Pinus-Betula-Larix LPAZ (samples from 225-278 cm depth), with similar values of Pinus sylvestris t. (up to $40 \%$ ) and Betula undiff. (up to $41 \%$ ) and a continuous percentage curve of Larix, represents the transformation of birch forests into pine-birch forests with larch. The vegetation of open areas was still widespread. This zone is correlated with the SO1-3 Carex rostrata-Urtica dioica (samples from 267.5-283 cm depth) and the older part of the SO1-4 Carex rostrata-Urtica dioica-Ranunculus sceleratus -Nuphar L MAZs (samples from $222.5-258.5 \mathrm{~cm}$ depth). Vegetation growing on the lake shore and forming the rush belt became impoverished due to a rise in water level, as indicated by the preserved remains (ephippia) of Daphnia sp. These indicate that the lake was deep, with quite cool water and a low trophic level (Szeroczyńska and Zawisza, 2011).

SO1-3 Picea-Alnus-Fraxinus-/Ulmus/ LPAZ (samples from $160-215 \mathrm{~cm}$ depth). Upwards in the zone the pollen values of Pinus, Betula and Larix gradually decrease, those of Picea, Alnus, Fraxinus and Ulmus increase, and continuous percentage curves of Quercus, Taxus, Tilia and Corylus appear. The frequencies of Cyperaceae also increase considerably, and continuous curves of Artemisia and Humulus appear. Spores of Filicales monolete are frequent.

This zone represents the beginning of the formation of wet communities of alder carr type with spruce, and ash-alder riverine forests, probably with oak (?Quercus robur). The latter species could have entered pine communities forming mixed pine-oak forests. The zone is correlated with the younger part of the S01-4 LMAZ (samples from 172.5-212.5 cm depth). The remains of Urtica dioica and Stellaria nemorum indicate that these were abundant in the herb layer of the alder carr forests. Ranunculus sceleratus and Rumex maritimus grew on the exposed, muddy, periodically flooded shores. The remains of Carduus crispus (fruits) indicate that this probably grew in wet places. The sun-exposed slopes were the habitat for xerophytic Fragaria vesca (seeds), Dianthus arenarius (seeds) and Potentilla heptaphylla (seeds). The rush belt was again the habitat of many abundantly growing species. The predominant Carex rostrata formed high sedge rush. It was accompanied by Typha, Schoenoplectus lacustris, Sparganium emersum, S. microcarpum and Hippuris vulgaris. A considerable shallowing of the lake is indicated by the development of Nymphaeaceae, the main representative of which was Nuphar lutea (seeds). Potamogeton natans and $P$. dorofeevi (endocarps) as well as Ceratophyllum demersum (fruits) occured among submerged hydrophytes. The last of these occurs in eutrophic, stagnant or slowly flowing water, and is intolerant of considerable decreases in water level and of drying. However, the lake was meso/eutrophic as indicated by the occurrence of Najas flexilis with an ecological optimum in mesotrophic water.

SO1-4 Taxus-Quercus-Abies-/Carpinus/ LPAZ (samples from 130-155 cm depth) is characterized by an increase in the pollen values of Picea up to $17 \%$, Alnus up to $19 \%$, Taxus up to $2 \%$ and Corylus up to $2.5 \%$, decreasing frequencies of Betula undiff. to $2 \%$, and values of Pinus sylvestris t. ranging from 31 to $50 \%$. In the upper part of the zone the appearance of continuous pollen curves of Abies and Carpinus with maxima of 13 and $5 \%$, respectively, and the occurrence of pollen of thermophilous plants (Pterocarya, Buxus, Hedera, Ilex, Ligustrum, Vitis, Viscum) is notable. Different taxa of the Ericaceae family are abundant among dwarf shrubs, and Salvina natans occurs among water plants.

The zone represents forest communities of the beginning of the Mazovian (=Holsteinian) Interglacial optimum. These were wet forests of different types (riparian forests, spruce forests with alder, alder carr forests with yew), fir forests, and dry-soil forests with hornbeam, oak, maple and lime. Thermophilous shrubs and climbers occurred in these forests. The zone is correlated with the SO1-5 LMAZ Salvinia natans-Azolla filiculoides (samples from 132.5-162.5 cm depth). The occurrence of these two species of thermophilous water ferns, typical of shallow, warm lakes of the Middle Pleistocene, indicates a lowering of water level. The development of rush was hindered. Only 
reeds with Typha could have survived because dense mats of fern covered the surface of the oxbow lake. The development of macrophytes was hindered, among others of Nymphaeaceae, which completely disappeared.

SO1-5 Pinus LPAZ (samples from 105-125 cm depth) is characterized by a lower frequency of sporomorphs, which are mostly degraded, especially in the two top samples. Among AP Pinus sylvestris $\mathrm{t}$. is predominant $(54-66 \%)$, the values of Betula undiff. slightly increase (up to $10 \%$ ). Abies (up to $3 \%$ ), Picea (up to $7 \%$ ), Alnus (up to $3 \%$ ) and Carpinus (up to $1 \%$ ) have continuous curves. Pollen of Ulmus, Fraxinus, Quercus and Taxus appear only sporadically. The values of Cyperaceae, Poaceae, Artemisia and Rumex acetosa are again slightly higher. The occurrence of Comarum palustre, Scheuchzeria palustris and Drosera rotundifolia, as well as the decreasing spore values of Filicales monolete suggests the development of a mire. Among plant macrofossils only tegmens of Typha sp. are found (sample from $112.5 \mathrm{~cm}$ depth).

This zone reflects further domination by pine forests in the study area. The gradually increasing degree of destruction of sporomorphs and their decreasing frequency, as well as the change of the deposit into a mineral-organic one, indicate that a hiatus coincided with the younger part of the climate optimum.

The succession described, i.e. boreal birch forests (SO1-1 LPAZ) and birch-pine forests with larch (SO1-2 LPAZ), which developed at the beginning of the interglacial, followed by alder-spruce communities with gradually appearing elements representing warmer climate (ash, elm, oak - SO1-3 LPAZ), and then with yew, fir, hornbeam, lime, maple and hazel (SO1-4 LPAZ), is typical of the older part of the Mazovian Interglacial. The latter zone contains several thermophilous plant elements indicating a warm and wet climate. These are, among others, climbers (Hedera, Humulus and Vitis), shrubs (Buxus, Ligustrum, Ilex and Viscum) and water ferns (Salvinia natans and Azolla filiculoides). Simultaneously occurring high values of fir and hornbeam, typical of the Mazovian optimum (Mamakowa,
2003), are not recorded in the pollen diagram. However, a very good correlation is found with the pollen diagram of the Mazovian succession from the nearby Domaszki site (cf. Pidek et al., 2011) reflecting the development of communities dominated by Carpinus and Abies. This additionally supports the Mazovian age of the succession investigated. A distinct sign of its Middle Pleistocene age is also the occurrence of Pterocarya and Azolla, which did not occur in the Eemian and the Holocene. The pattern of vegetation development in the lake is also similar to that recorded in the plant macrofossils of lakes elsewhere in central-eastern Poland during the Mazovian Interglacial (cf., among others, Hrynowiecka and Szymczyk, 2011).

\section{LUMINESCENCE DATING}

The equivalent dose and sample age values obtained using the TL method are shown in Table 5, and those obtained using the IRSL method are in Table 6. According to Li and Li (2011), in the MET-pIRIR procedure the deposit age should be determined using the average ED value (calculated ED values for $250^{\circ} \mathrm{C}$ and $300^{\circ} \mathrm{C}$ ). The IRSL $L_{M E T}$ age shown in Table 4 was calculated in this way.

The luminescence dates of the point bar deposits form two distinct groups.

The younger dates of the point bar deposits were obtained by IRSL methods (MET-pIRIR: $303 \pm 19$ ka and $338 \pm 21 \mathrm{ka}$, and pIRIR 290 : $352 \pm 33 \mathrm{ka}$ and $364 \pm 33 \mathrm{ka}$ ). These results are outside the range of applicability of these methods, which is determined at 300 ka because the higher values are underestimated in relation to the expected age (e.g., Yi et al., 2012). Therefore, the dating results obtained for the point bars using the IRSL methods are underestimated.

The older dates of the point bar deposits were obtained using TL methods ( $\mathrm{TL}_{\mathrm{MAX}}$ : 412-445 ka and TL $\mathrm{INT}_{\mathrm{NT}}$ : 408-631 ka). The age obtained by these methods may be overestimated due to short transport of the sediment before its deposition. Short

The equivalent doses and TL ages of the deposits determined by two means

\begin{tabular}{|l|c|c|c|c|c|c|c|}
\hline Sample & $\begin{array}{c}\text { Depth } \\
{[\mathrm{m}]}\end{array}$ & $\begin{array}{c}\text { Plateau } \\
\text { test } \\
{\left[{ }^{\circ} \mathrm{C}\right]}\end{array}$ & $\begin{array}{c}\text { Max. TL curve } \\
{\left[{ }^{\circ} \mathrm{C}\right]}\end{array}$ & $\begin{array}{c}\text { Equivalent dose ED } \\
{[\mathrm{Gy}]}\end{array}$ & $\begin{array}{c}\mathrm{TL}_{\text {MAX }} \text { age } \\
{[\mathrm{ka}]}\end{array}$ & $\begin{array}{c}\text { Equivalent dose ED } \\
{[\mathrm{Gy}]}\end{array}$ & $\begin{array}{c}\mathrm{TL}_{\text {INT }} \text { age } \\
{[\mathrm{ka}]}\end{array}$ \\
\hline SPB-1 & 1.4 & $276-295$ & 281 & $1106 \pm 197$ & $444 \pm 80$ & $1283 \pm 294$ & $515 \pm 118$ \\
SPB-2 & 3.4 & $239-290$ & 282 & $1198 \pm 123$ & $431 \pm 45$ & $1134 \pm 151$ & $408 \pm 57$ \\
SPB-3 & 2.4 & $262-282$ & 279 & $806 \pm 121$ & $424 \pm 64$ & $1190 \pm 245$ & $626 \pm 134$ \\
SPB-4 & 3.2 & $273-295$ & 279 & $1256 \pm 177$ & $433 \pm 61$ & $1183 \pm 197$ & $408 \pm 69$ \\
SPB-5 & 3.4 & $284-313$ & 287 & $1509 \pm 226$ & $445 \pm 67$ & $2138 \pm 191$ & $631 \pm 76$ \\
SPB-6 & 2.0 & $276-290$ & 279 & $422 \pm 65$ & $412 \pm 63$ & $532 \pm 90$ & $522 \pm 99$ \\
\hline
\end{tabular}

The equivalent dose and deposit age values determined using the pIRIR $\mathbf{2 9 0}_{20}$ and MET-pIRIR procedures

\begin{tabular}{|c|c|c|c|c|c|c|c|}
\hline \multicolumn{5}{|c|}{$\mathrm{pIRIR}_{290}$} & \multicolumn{3}{|c|}{ MET-pIRIR } \\
\hline Profile & $\begin{array}{l}\text { Depth } \\
\text { [m] }\end{array}$ & $\begin{array}{c}\text { Equivalent dose } \\
\text { ED plRIR290 } \\
{[G y]}\end{array}$ & $\begin{array}{c}\mathrm{IRSL}_{p|R| R 290} \text { age } \\
{[\mathrm{ka}]}\end{array}$ & $\begin{array}{c}\text { Equivalent dose } \\
\text { ED } \\
\text { MET-pIRIR250 } \\
{[G y]}\end{array}$ & $\begin{array}{c}\text { Equivalent dose } \\
\text { ED }_{\text {MET-pIRIR300 }} \\
{[G y]}\end{array}$ & $\begin{array}{c}\text { Equivalent dose } \\
\text { ED }_{\text {MET-pIRIRmid }} \\
{[G y]}\end{array}$ & $\begin{array}{c}I_{\text {IRSL }} \text { MET-pIRIRmid } \\
\text { age } \\
\text { [ka] }\end{array}$ \\
\hline SPB-1 & 1.4 & $877 \pm 70$ & $352 \pm 33$ & $785 \pm 53$ & $726 \pm 55$ & $755 \pm 30$ & $303 \pm 19$ \\
\hline SPB-2 & 3.4 & $1013 \pm 76$ & $364 \pm 33$ & $914 \pm 57$ & $968 \pm 61$ & $941 \pm 27$ & $338 \pm 21$ \\
\hline \multicolumn{8}{|c|}{ Recycling ratio } \\
\hline SPB-1 & 1.4 & $1.00 \pm 0.01$ & & $1.01 \pm 0.01$ & $0.96 \pm 0.01$ & & \\
\hline SPB-2 & 3.4 & $1.04 \pm 0.01$ & & $1.01 \pm 0.01$ & $0.99 \pm 0.01$ & & \\
\hline
\end{tabular}


sediment transport hinders total bleaching of the deposits (Łanczont et al., 2013). Such a situation can be excluded in the case of point bars because channel deposits are formed in the middle and lower reaches of river valleys, i.e. a long distance from the source area. However, the wide time span of their deposition as indicated by the $\mathrm{TL}_{\mathrm{INT}}$ method is not plausible. This would include the period from MIS 13 to MIS 11, that is, two interglacial periods separated by a glacial (Fig. 1). In this case the meandering river pattern should have been transformed into a braided one during the glacial correlated with MIS 12; this is not recorded in the deposits investigated. Therefore, the most probable age of the point bar is given by the $T L_{\text {MAX }}$ method: 412-445 ka. This age corresponds to the final phase of the Sanian 2/Elsterian Glaciation and the beginning of the Mazovian (=Holsteinian) Interglacial (MIS 12-11; Fig. 1). The results of thermoluminescence dating indicate that the $T L_{\text {MAX }}$ method is the most reliable in the assessment of the section studied.

Similar TL results (approx. $430 \mathrm{ka}$ ) have been obtained for silty sands underlying organic-clastic deposits of Mazovian/Holsteinian age in eastern Poland (Nitychoruk et al., 2005). These dates correspond to the end of the Sanian 2/Elsterian Glaciation (MIS 12; Fig. 1).

\section{SUMMARY OF RESULTS AND CONCLUSIONS}

Two waterlain Pleistocene successions of different origin have been identified by detailed sedimentological analysis of the present-day Samica valley infill: glaciofluvial unit B and fluvial unit $C$. These deposits are characterized by distinct textural and structural features. Glaciofluvial unit B, containing channelized facies, reflects a braided fluvial system typical of severe cold climate. By contrast, the younger unit $C$ composed of point-bar (subunit C-1) and oxbow facies (subunit C-2) was deposited in a meandering river, a fluvial environment characteristic of a temperate climate. Moreover, these fluvial systems flowed in opposite directions: the glaciofluvial water flowed southwards, and the meandering river to the north.

The stratigraphic position of fluvial unit $C$ was determined by means of palaeobotanical analyses of oxbow lake deposits (subunit C-2) as well as indirectly by petrographic analysis of the till (unit $A$ ) in which the fluvial deposits are incised. Luminescence dating of point-bar deposits (subunit C-1) was carried out to estimate the age of fluvial unit C. Our findings lead to the following stratigraphic conclusions:

1. Petrographic analysis indicates that the basal till of the till plain contains indicator erratics typical of south-western Fennoscandia. The Theoretical Boulder Centre (TBC: $18.29^{\circ} \mathrm{E}$ and $59.13^{\circ} \mathrm{N}$ ) is similar to that calculated for tills of the San 2/Elsterian Glaciation (MIS 12) in central-eastern Poland. Thus, the formation of the Samica River fossil valley started after this ice-sheet retreat.

2. Based on palaeobotanical analyses of the oxbow deposits, the succession was divided into five local pollen zones (LPAZs) and five local macrofossil zones (LMAZs). The first four L PAZs, correlated with the LMAZs, are typical of the older part of the Mazovian (=Holsteinian) Interglacial. They represent the following successive phases of vegetation development:

- open birch forest at the beginning of the interglacial. A shallow lake with poor lakeshore vegetation, and cool and mesotrophic lake water;

- birch-pine forest. A rise in water level in the lake and impoverishment of the lakeshore vegetation composition. The lake water was still cool and weakly mesotrophic.

- Wet forest of alder carr type, and ash-alder riverine forest. The shallowing lake was surrounded by a wide belt of high sedge rush. The lake water was warm, meso/eutrophic;

- thermophilous and hygrophilous forest communities around the lake, including a riverine forest with Pterocarya during the climatic optimum of the interglacial. The still shallowing lake was overgrown by water ferns - Salvinia natans and Azolla filiculoides.

3. The luminescence ages of the point bar deposits form two distinct groups:

- younger ages were obtained by IRSL methods (MET-pIRIR: $303 \pm 19 \mathrm{ka}$ and $338 \pm 21 \mathrm{ka}$, and pIRIR 290 : $352 \pm 33 \mathrm{ka}$ and $364 \pm 33 \mathrm{ka}$ ). The results are outside the range of applicability of these methods (300 ka), and so are underestimated;

- older ages were obtained by TL methods ( $T L_{\text {MAX: }}$ 412-445 ka and TL $\mathrm{L}_{\mathrm{NT}}$ : 408-631 ka). As the deposition of the point bar deposits was continuous, we have to exclude the broad time span obtained by the $\mathrm{TL}_{\mathrm{INT}}$ method. The most probable age of these deposits is indicated by the results from the $T L_{\text {MAX }}$ method: $412-445 \mathrm{ka}$. These correspond to the end of the San 2/Elsterian Glaciation and the beginning of Mazovian/Holsteinian Interglacial (MIS 12-11).

The results obtained using the three different methods are compatible, and indicate that the alluvial deposits under study were formed in a river channel and oxbow lake from the end of Elsterian to the optimum of the Mazovian (=Holsteinian) Interglacial. These are the first Holsteinian fluvial deposits to be studied sedimentologically in Poland and indeed in Central Europe.

Other stratigraphical methods usefully complemented the palaeobotanical analyses. Lithofacies analysis enabled recognition of meandering river deposits typical of warm climatic conditions. Petrographic analysis of gravels larger than $20 \mathrm{~mm}$, still rare as a technique, allowed assignation of till levels to particular glacial periods. The use of the $T L_{\text {MAX }}$ method in dating deposits older than $400 \mathrm{ka}$ has been confirmed.

Acknowledgements. This work has been financially supported by the Polish Ministry of Science and Higher Education project no. N N306 198739 "Climatic cycles of Middle Pleistocene recorded in sedimentary succession in the Łuków region (E Poland)". The valuable comments of P. Gibbard and an anonymous reviewer were of great help in improving the manuscript.

\section{REFERENCES}

Adamiec, G., Aitken, M.J., 1998. Dose-rate conversion factors: update. Ancient TL, 16: 37-50.
Aitken, J.F., 1998. Sedimentology of Late Devensian glaciofluvial outwash in the Don Valley, Grampian Region. Scottish Journal of Geology, 34: 97-117. 
Albrycht, A., 2004. Szczegółowa mapa geologiczna Polski w skali 1: 50 000, ark. Sarnaki wraz z objaśnieniami. Państwowy Instytut Geologiczny, Warszawa.

Benea, V., Vandenberghe, D., Timar, A,. Van den Haute, P., Cosma, C., Gligor, M., Florescu, C., 2007. Luminescence dating of Neolithic ceramics from Lumea Noua, Romania. Geochronometria, 28: 9-16.

Bennike, O., Houmark-Nielsen, M., Bocher, J., Heinberg, E.O., 1994. A multi-disciplinary macrofossil study of Middle Weichselian sediments at Kobbelgard, Mon, Denmark. Palaeogeography, Palaeoclimatology, Palaeoecology, 111: 1-15.

Ber, A., Lindner, L., Marks, L., 2007. Proposal of a stratigraphic subdivision of the Quaternary of Poland. Quaternary International, 167-168: 32.

Berger, G.W., 1988. Dating Quaternary events by luminescence. GSA Special Paper, 227: 13-50.

Berger, G.W., Pillans, B.J., Palmer, A.S., 1992. Dating loess up to 800 ka by thermoluminescence. Geology, 20: 403-406.

Blakey, R.C., Gubitos, R., 1984. Controls of sandstone body geometry and architecture in the Chinle Formation (Upper Triassic) Colorado Plateau. Sedimentary Geology, 38: 51-86.

Bluszcz, A., 2000. Luminescence dating of Quaternary sediments theory, limitations, interpretation problems. Geochronometria, 17: 1-104.

Boulton, G.S., Hindmarsh, R.C.A., 1987. Sediment deformation beneath glaciers: rheology and geological consequences. Journal of Geophysical Research, 92: 9059-9082.

Cohen, K.M., Gibbard, P.L., 2010. Global chronostratigraphic correlation table for the last 2.7 million years. www.quaternary.stratigraphy.org.uk

Czubla, P., 2001. Fennoscandian erratics in Quaternary deposits of Middle Poland and their value for stratigraphic purposes (in Polish with English summary). Acta Geographica Lodziensia, $\mathbf{8 0}$ $1-174$.

Czubla, P., 2006. The stratigraphic significance of indicator erratics counts from glacial deposits - an example from Eastern Wielkopolska (Great Poland Lowland). Archiv für Geschiebekunde [Festband Gerd Lüttig] 5 (1-5): 177-190.

Czubla, P., Forysiak, J., Petera-Zganiacz, J., 2010a. Lithological and petrographic features of tills in the Koźmin region and their value for stratigraphical interpretation of glacial Lake Koźmin deposits, Central Poland. Geologija, 52: 1-8.

Czubla, P., Terpiłowski, S., Godlewska, A., 2010b. Koncepcje maksymalnego zasięgu lobu Bugu lądolodu zlodowacenia warty a skład eratyków przewodnich najmłodszych glin lodowcowych. In: XVII Konferencja Stratygrafia Plejstocenu Polski „Dynamika zaniku lądolodu podczas fazy pomorskiej w północnowschodniej części Pojezierza Mazurskiego", Jeziorowskie 6-10 września 2010 (eds. L. Marks and K. Pochocka-Szwarc): 56-57. Materiały konferencyjne, Warszawa.

Dobracki, R., Krzyszkowski, D., 1997. Sedimentation and erosion at the Weichselian ice-marginal zone near Golczewo, NW Poland. Quaternary Science Reviews, 16: 721-740.

Dreimanis, A., 1989. Tills, their genetic terminology and classification. In: Genetic Classification of Glacigenic Deposits (eds. R.P. Goldthwait and C.L. Matsch): 17-84. Balkema, Rotterdam.

Edwards, M.B., Eriksson, K.A., Kier, R.S., 1983. Palaeochannel geometry and flow patterns determined from exhumed Permian point bars in North-Central Texas. Journal of Sedimentary Petrology, 53: 1261-1270.

Frechen, M., 1992. Systematic thermoluminescence dating of two loess profiles from the Middle Rhine Area (F.R.G.). Quaternary Science Reviews, 11: 93-101.

Frechen, M., Zander, A., Cilek, V., Ložek, V., 1999. Loess chronology of the Last Interglacial /Glacial cycle in Bohemia and Moravia, Czech Republic. Quaternary Science Reviews, 18: 1467-1493.

Gibling, M.R., Rust, B.R., 1987. Evolution of a mud-rich meander belt in the Carboniferous Morien Group, Nova Scotia, Canada. Bulletin of Canadian Petroleum Geology, 35: 24-33.
Górska, M., 2006. Fennoscandian erratics in glacial deposits of the Polish Lowland - methodical aspects. Studia Quaternaria, 23: 11-15.

Górska-Zabielska, M., 2008. Fennoskandzkie obszary alimentacyjne osadów akumulacji glacjalnej i glacjofluwialnej lobu Odry. Wydawnictwo Naukowe UAM, Poznań, Seria Geografia, 78: 1-330

Hart, J.K., Boulton, G.S., 1991. The interrelationship between glaciotectonic deformation and glaciodeposition within the glacial environment. Quaternary Science Reviews, 10: 335-350.

Hoffmann, K., Meyer, K.-D., 1999. Indicator stone counts on Elsterian and Saalian sediments from Eastern Germany. Geological Quarterly, 43 (2): 233-240.

Hrynowiecka, A., Szymczyk, A., 2011. Preliminary results of comprehensive palaeobotanical studies of peat bog sediments from the Mazovian/Holsteinian interglacial at the site of Nowiny Żukowskie (SE Poland). Bulletin of Geography, 4: 21-46.

Kolstrup, E., 1979. Herbs as July temperature indicators for parts of the Pleniglacial and the Late-glacial in the Netherland. Geologie en Mijnbouw, 59: 337-380.

Janczyk-Kopikowa, Z., 1987. Remarks on palynostratigraphy of the Quaternary (in Polish with English summary). Geological Quarterly, 31 (1): 155-162.

Krzyszkowski, D., 1992. Czwartorzed rowu Kleszczowa litostratygrafia i tektonika. Zarys problematyki na podstawie obserwacji w odkrywce KWB „Bełchatów”. Acta Universitatis Wratislaviensis, 1252, Studia Geograficzne, 54: 1-158.

Kusiak, J., 2008. Kontekst stratygraficzny zastosowania różnych odmian metody termoluminescencyjnej w datowaniu lessów z terenu Polski południowo-wschodniej i Ukrainy północno-zachodniej. Annales UMCS, B, 63: 21-60.

Kusiak, J., Łanczont, M., Madeyska, T., Bogucki, A.B., 2013 Problems of TL dating of the Mesopleistocene loess deposits in the Podillya and Pokuttya regions (Ukraine). Geochronometria, 40 (1): 51-58

Krüger, J., Kjær, K.H., 1999. A data chart for field description and genetic interpretation of glacial diamicts and associated sediments - with examples from Greenland, Iceland, and Denmark. Boreas, 28: 386-402.

Li, B., Li, S.H., 2011. Luminescence dating of K-feldspar from sediments: a protocol without anomalous fading correction. Quaternary Geochronology, 6: 468-479.

Lindner, L., Marks, L., 2012Climatostratigraphic subdivision of the Pleistocene Middle Polish Complex in Poland (in Polish with English summary). Przegląd Geologiczny, 60: 36-45.

Lindner, L., Lamparski, Z., Dąbrowski, S., 1982. River valleys of the Mazovian Interglacial in the eastern Central Europe. Acta Geologica Polonica, 32: 179-190.

Lüttig, G., 1958. Methodische Fragen der Geschiebeforschung Geologisches Jahrbuch, 75: 361-418.

Lüttig, G., 2005. Geschiebezählungen im westlichen Mecklenburg. Archiv für Geschiebekunde 4: 569-608

Łanczont, M., Bogucki, A.B., Fedorowicz, S., Kusiak, J., 2011. Mesopleistocene loess deposits in the Mamalyha 2 profile of Ukraine - interlaboratory comparison of the thermoluminescence dating results. Geochronometria, 38: 350-358.

Łanczont, M., Bogucki, A.B., Kusiak, J., Sytnyk, O., 2013. The results of thermoluminescence dating in the Halych Ilc (Ukraine) profile as the expression of the conditions of mineral material deposition. Geochronometria, 40 (1): 42-50.

Małek, M., 2004. Szczegółowa mapa geologiczna Polski 1: 50000 arkusz Siedlce Południe wraz z objaśnieniami. Państwowy Instytut Geologiczny, Warszawa.

Małek, M., Buczek, K., 2009. Szczegółowa mapa geologiczna Polski 1: 50 000, arkusz Łuków. Państwowy Instytut Geologiczny, Warszawa.

Mamakowa, K., 2003. Plejstocen. In: Palinologia (eds. S. Dybova-Jachowicz and A. Sadowska): 235-266. Wyd. IB PAN, Kraków. 
Marks, L., 2004. Zasięg lądolodu zlodowacenia warty w Polsce. In: Zlodowacenie warty w Polsce (eds. M. Harasimiuk and S. Terpiłowski): 27-36. Wyd. UMCS, Lublin.

Marks, L., Pavlovskaya, I.E., 2003. The Holsteinian Interglacial river network of mid-eastern Poland and western Belarus. Boreas, 32: 337-346.

Marren, P.M., Russell, A.J., Rushmer, E.L., 2009. Sedimentology of a sandur formed by multiple jokulhlaups, Kverkfjoll, Iceland. Sedimentary Geology, 213: 77-88.

Matuszkiewicz, W., 2001. Przewodnik do oznaczania zbiorowisk roślinnych Polski. Vademecum Geobotanicum. PWN, Warszawa.

Meyer, K.-D., 1983. Indicator pebble and stone count methods. In: Glacial deposits in North-West Europe (ed. J. Ehlers): 275-287. A.A. Balkema, Rotterdam.

Miall, A.D., 1978. Lithofacies types and vertical profile models in braided rivers: a summary. Canadian Society of Petroleum Geologists Memoir, 5: 597-604.

Miall, A., 1996. The Geology of Fluvial Deposits. Sedimentary Facies, Basin Analysis, and Petroleum Geology. Springer, Berlin

Murray, A.S., Wintle, A.G., 2000. Luminescence dating of quartz using an improved single-aliquot regenerative-dose protocol. Radiation Measurements, 32: 57-73.

Nalepka, D., Walanus, A., 2003. Data processing in pollen analysis. Acta Palaeobotanica, 43: 125-134.

Nitychoruk, J., Bińka, K., Hoefs, J., Ruppert, H., Schneider, J., 2005. Climate reconstruction for the Holsteinian Interglacial in eastern Poland and its comparison with isotopic data from Marine Isotope Stage 11. Quaternary Science Reviews, 24 631-644.

Olsen, H., Andreasen, F., 1995. Sedimentology and ground-penetrating radar characteristics of a Pleistocene sandur deposit. Sedimentary Geology, 99: 1-15.

Økland, K.A., Økland, J., 2000. Freshwater bryozoans (Bryozoa) of Norway distribution and ecology of Cristatella mucedo and Paludicella articulate. Hydrobiologia, 421: 1-24.

Pidek, I.A., Terpiłowski, S., Małek, M., 2011. Succession of the Mazovian Interglacial near Łuków (E Poland): palynostratigraphic and palaeogeographic approach. Geologija, 53 (1): 27-35.

Pisarska-Jamroży, M., Zieliński, T., 2014. Pleistocene sandur rhythms, cycles and megacycles: Interpretation of depositional scenarios and palaeoenvironmental conditions. Boreas, 43: 330-348.

Prescott, J.R., Hutton, J.T., 1994. Cosmic ray contributions to dose-rates for luminescence and ESR dating: large depths and long term variations. Radiation Measurements, 23: 497-500.

Siegenthaler, C., Huggenberger, P., 1993. Pleistocene Rhine gravel: deposits of a braided river system with dominant pool preservation. Geological Society Special Publications, $\mathbf{7 5}$ 147-162.

Smed, P., 1993. Indicator Studies: a critical review and a new data-presentation method. Bulletin of the Geological Society of Denmark, 40: 332-344.
Smith, D.G., 1987. Meandering river point bar lithofacies models: modern and ancient examples compared. SEPM Special Publication, 39: 83-91.

Stachowicz-Rybka, R., 2011. Flora and vegetation changes on the basis of plant macroremains analysis from an early Pleistocene lake of Augustów Plain, NE Poland. Acta Palaeobotanica, 51: 39-103.

Steijn, H., van, Bertran, P., Francou, B., Hétu, B., Texier, J.P., 1995. Models for the genetic and environmental interpretation of stratified deposits: review. Permafrost and Periglacial Processes, 6: 125-146.

Szeroczyńska, K., Zawisza, E., 2011. Records of the 8200 cal BP cold event reflected in the composition of subfossil Cladocera in the sediments of three lakes in Poland. Quaternary International, 233: 185-193.

Terpiłowski, S., 2001. Strefa marginalna lądolodu warciańskiego na Wysoczyźnie Siedleckiej w świetle analizy litofacjalnej. Wyd. UMCS, Lublin.

Thiel, C., Buylaert, J.P., Murray, A., Terhorst, B., Hofer, I., Tsukamoto, S., Frechen, M., 2011. Luminescence dating of the Stratzing loess profile (Austria) - Testing the potential of an elevated temperature post-IR IRSL protocol. Quaternary International, 234: 23-31.

Thomas, R.G., Smith, D.G., Wood, J.M., Visser, J., Calverley-Range, E.A., Koster, E.H., 1987. Inclined heterolithic stratification - terminology, description, interpretation and significance. Sedimentary Geology, 53: 123-179.

Van der Meer, J.J.M., Menzies, J., Rose, J., 2003. Subglacial till: the deforming glacier bed. Quaternary Science Reviews, 22: 1659-1685.

Velichkevich, F.Y., Zastawniak, E., 2006. Atlas of the Pleistocene vascular plant macrofossils of Central and Eastern Europe, Part 1 - Pteridophytes and monocotyledons. W. Szafer Institute of Botany, Polish Academy of Sciences, Kraków.

Vinx, R., Grube, A., Grube, F., 1997. Vergleichende Lithologie, Geschiebeführung und Geochemie eines Prä-Elster-I-Tills von Lieth bei Elmshorn. Leipziger Geowissenschaften, 5: 83-103.

Wallinga, J., Murray, A., Wintle, A., 2000. The single-aliquot regenerative-dose (SAR) protocol applied to coarse-grained feldspar. Radiation Measurements, 32: 529-533.

West, R.G., 1970. Pollen zones in the Pleistocene of Great Britain and their correlation. New Phytologist, 69: 1179-1183.

Wood, J.M., 1989. Alluvial architecture of the Upper Cretaceous Judith River Formation, Dinosaur Provincial Park, Alberta, Canada. Canadian Petroleum Geology Bulletin, 37: 169-181.

Yi, S., Lu, H., Stevens, T., 2012. SAR TT-OSL dating of the loess deposits in the Horqin dunefield (northeastern China). Quaternary Geochronology, 10: 56-61.

Zieliński, T., Pisarska-Jamroży, M., 2012. Which features of deposits should be included in the code and which not? (in Polish with English summary). Przegląd Geologiczny, 60: 387-397. 